


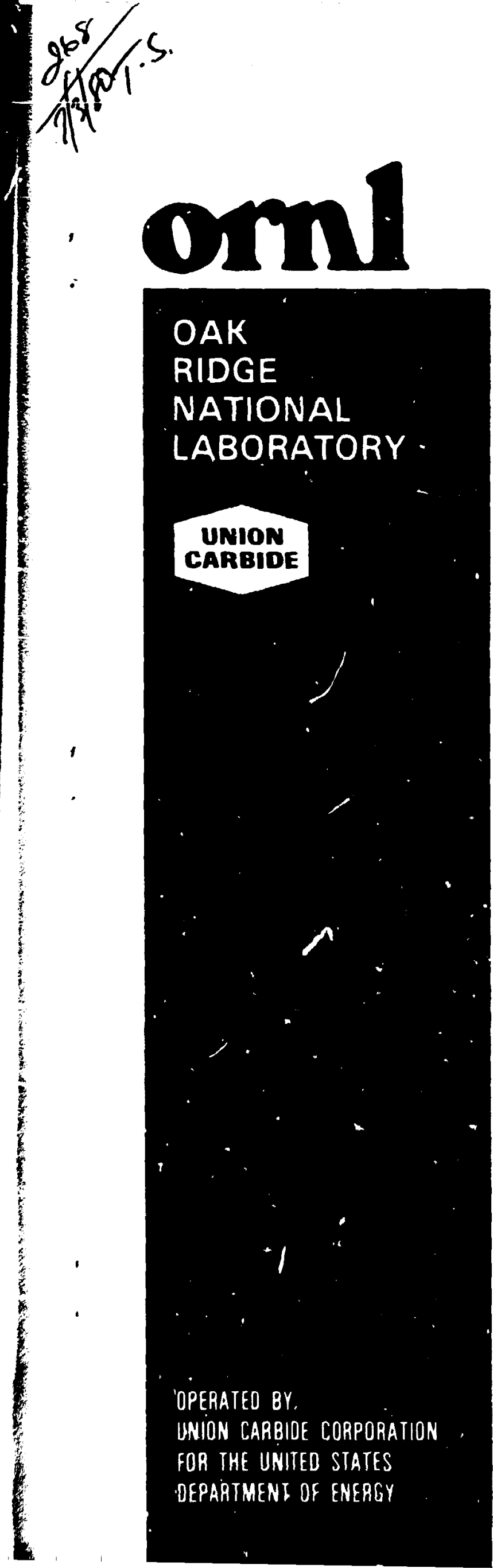

ORNL-5464

\section{Radiological Survey of the Inactive Uranium-Mill Tailings at Lakeview, Oregon}
F. F. Haywood
J. E. Burden
B. S. Ellis
E. T. Loy
W. H. Shinpaugh

P's ?

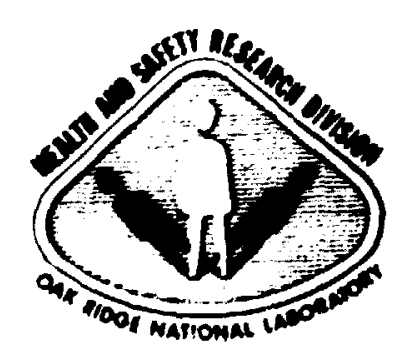


Contract No. W-7405-eng-26

Health and Safety Pesearch Division

\section{RADIOLOGICAL SURVEY OF THE INACTIYE URANIUA-MILL TAILINGS AT LAKEVIEW, OREGON}

F. F. Haywood, J. E. Burden, B. S. Ellis, E. T. Loy, and W. H. Shinpaugh

Date Published: June 1980

Appendix $I$ in this document is a direct reproduct on of the Phase I interagency site visit prepared by Lucius Pitkin, Inc., under AEC Contract AT(05-1)912.

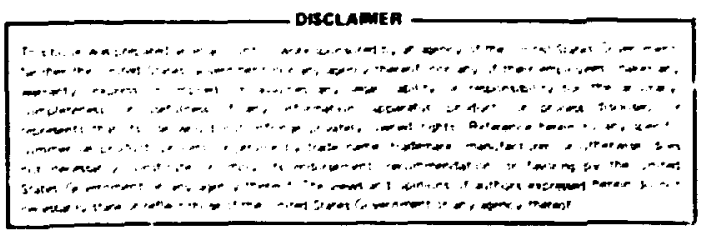

OAK RIDGE NATIONAL LABORATORY

Oak Ridge, Tennessee 37830

operated by

UNION CARBIDE CORPORATION

for the

DEPARTMENT OF ENERGY 
LIST OF REPORTS OF OAR RIDGE MAIIONAL LABCRATORY RAOIOLOGICAL SURVEYS AT IMACTIVE URANIUA-MILL SITES

Assessment of Radislogical Impact of the Inactive UraniumMill Tailings Pile at Salt Lake City. Utan

ORML/TM-5251

Assessment of the Radiological Impact of the Inactive UraniunMill Tailings at Shiprock. New Hexico

ORKL-5447

Assessment of the Rasiological Imact of the Inactive UranitarMill Tailings at Mexican Hat, Utan

Assessment of the Radiological Impact of the Inactive 'J-anive Mill Ia.lings Piles at Monument Valley, Arizona

Radiological Survey of the Inactive Uranium-Mill Tailings at Tuba City, Arizona

Raviological Survey of the Inactive Uranium-Miil Tai?ings at Durango. Colorado

Radiological Survey of the Inactive Uranium-Mill Ta lings at Slick Rock. Colorade

Radiological Survey of the Inactive Uraniua-Mill taitings at Gunnison. Colorado

Radiolngica: Survey of the Inac: ive Uranium-Mili failings at Maturita. Coloraos

Radiological Survey of the Inactive Uraniun-Mill railincs at Rifle, Colorado

Radiological Survey of the Inactive Uranium-Mill iailings at Maybe 11, Colorado

Assessment of the Radiological Impact of the Iractive UraniumMill Tailings at Grand Junction, Colorado

Radiological Survey of the Inactive Uranium-Mi!: iailings at Ambrosia Lake, New Mexico

Rasiological Survey of the Inactive Uranium-Mill Tailings at Green River, Utah

Radiulogica: Survey of the Inactive Uranium-Mill railings at the Spook Site. Converse Cuunty, Wyoming

Radiological Survey of the Inactive Uranitim-Mill Tailings at River:on, Wyoming

Radiological Survey of the Inactive Uraniup-Mill tailirigs at Falls Cily, Texas

Radialogical Survey of the Inactive Uranium-Mill Tailings, at Ray Point, Texas

Radiological Survey of the Inactive Uranium-Mill railings at Lakeview, Oregon

Radiological Survey of the Radioactive Sands ard Residues at Loman, Idaho 


\section{CONTENTS}

\section{Page}

LIST OF FIGURES . . . . . . . . . . . . . . . . iv

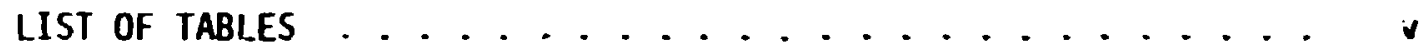

ACKNOWLEDGEMENTS ......................... vi

ABSTRACT ............................ ix

1. INTRODUCTION ......................... 1

2. SITE DESCRIPTION ...................... 1

3. SAMPLING TECHNIQUES AND RADIOLOGICAL MEASUREMENTS . . . . 3

4. RESULTS OF MEASUREMENTS ................. 3

4.1 Background Radioactivity ............ . 4

4.2 Direct Gamma-Ray Exposure Rates . . . . . . . . . 4

4.3 Concentration of ${ }^{226} \mathrm{Ra}$ in Surface Soil and Sediment Samples............ 7

4.4 Radiochemical Analysis of Water Samples . . . . . . . 11

4.5 Subsurface Distribution of ${ }^{226} \mathrm{Ra}$ in Soil and Tailings .................. 11

5. SUMMARY ..................... 16

REFERENCES ............................ 19

APPENDIX I - PHASE I. Report on Conditions of Uranium Millsite and Tailings at Lakeview, Oregon . . . . 21

APPENDIX II, Soil Sampling Techniques and Radiologicai Measurements........... 37

APPENDIX III, Water Sampling and Analysis .......... 51 


\section{! IST OF FIGURES}

Figure

1 Aerial view of the Lakeview site and surrounding

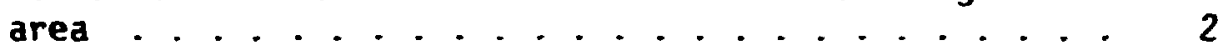

2 Locations of background external gama measurements and background surface soil samples......... 5

3 External gama exposure rates $1 \mathrm{~m}$ above the ground at the Lakeview site............. 8

4 Locations and identifications of environmental samples...................... 12

5 Locations of holes drilled at the Lakeview site . . . 14 


\section{LIST OF TABLES}

Table

Page

1 Locations of background external gama measurements and background surface soil samples around Lakeview,

Oregon .

2 Concentration of ${ }^{226} \mathrm{Ra}$ and ${ }^{232} \mathrm{Th}$ in surface soil and sediment samples at the Lakeview site ........ g

3 Concentration of ${ }^{226}$ Ra in water samples ........ 13

4 Calculated concentrations of ${ }^{226} \mathrm{Ra}$ as a function of depth in auger holss at the Lakeview site ........ 15

5 Comparison of measured and estimated concentrations

of ${ }^{226} \mathrm{Ra}$ in hand-dug hole near hole $22 \ldots 17$ 


\section{ACKNOWLEDGEMENTS}

The authors of this series of reports wish to express their deep appreciation to the following persons: tc L. J. Deal and R. H. Kennedy, Department of Energy, Washington, D. C., for their encouragement and support during the field operations phase of this project; to Dr. Charles J. Barton of Science Applications, Inc. (SAI), Oak Ridge, for his diligent work in preparing, inder subcontract, the drafts of this series, and to Wilma Minor, also of SAI, for typing the manuscripts; to the many members of the Health and Safety Research Division who provided technical reviews of the : idividual reports; to Jenny Vinson, Health and Safety Research Division Technical Editor, special thanks is extended for her careful review of each manuscript, especially for helping ensure that a uniform format was followed; to Dr. Barry Berven for his assistance in organizing the final drafts. Appreciation is extended to John G. Themelis and Frank McGinley, Department of Energy, Grand Junction Operations offica, for their support and advice during the conduct of this proje:t; to Charles Brunner, Bendix Field Engineering Company, Grand Junction, Colorado, for his assistance in arranging for the grinding of approximately 1600 soil samples which were collected during the project; also to Dr. Vern Rogers and his staff, Ford, Bacon and Davis Jtah Inc., for assistance during the field operations phase of this project. Finally, the authors wish to acknow edge the efforts of Mr. Ev Ha?dane, Department of Energy, Grand Junction, who was associated with the uranium-mill tailings program from its earliest days. Ev passed away suddenly on June 30,1979, and it is to his memory that this series of reports is dedicated. 


\section{RADIOLOGICAL. SURVEY OF THE INACTIVE URANIUMA-MILL}

TAILINGS AT LAKEVIEW, OREGON

F. F. Haywood, J. E. Burden, B. S. Ellis, E. T. Loy, and W. H. Shinfaugh

\section{ABSTRACT}

The resul. f the radiological survey of the inactive uranium-mill site at Lakeview, Oregon, presented in this report, show that the average gamma-ray exposure rate $1 \mathrm{~m}$ above the ailings pile and the evaporation pond area (now dry) is close to the average ba:kcround level for the area (11 $\mu R / h r)$. The ${ }^{226} R a$ concentration in most of the surface soil and sediment samples is also at or below the average background value for surface soil samples in the area $(0.8 \mathrm{pCi} / \mathrm{a})$. Calculated ${ }^{226} \mathrm{Ra}$ concentrations, based on gama radiation measurements in shallow (1-m-deep) holes, are in agreement with the results of surface soil and sediment analyses and with gama-ray exposure rate measurements. The tailings at this site have been stabilized by the addition of 46 to 60 $\mathrm{cm}$ (18 to $24 \mathrm{in.}$ ) of soil that supports vigorous growth of vegetation. This treatment, coupled with a low-level inventory of ${ }^{226} \mathrm{Ra}$ in the tailings $50 \mathrm{Ci})$, has resulted in limited spread of tailings by wind and water. 


\section{INTRODUCTION}

This is one of a series of reports on results of radiological surveys of uranium-mill tailings at inactive mill sites in the western United States. A list of the reports in this series is found at the front of this report. The first four reports, as well as the one on the Grand Junction site, include attempts to assess potential health effects of radiation and radionuclides from the sites. The first report ${ }^{1}$ also contains a discussion of modes of radiation exposure to individuals and to population groups resulting from the radionuclides in tailings at uranium-mill sites and a survey of the pertinent literature. The present report on the inactive mill site near Lakeview, Oregon, presents the results of 7 radiological survey conducted in 1976 together with descriptions of the apparatus and techniques used to obtain the data. The survey was conducted in cooperation with an engineering team from Ford, Bacon and Davis Utah Inc. (FB\&DU), the architect-engineering company responsible for the Phase II engineering assessment of the sites considered in this series. Their report on this site has been published. 2 Results of a gamma radiation survey of tr.ese sites [by the Environmental Protection Agency (EPA)] have also been published. ${ }^{3}$ The previously unpubiished Phase 1 engineering survey report on the visit to the Lakeview site by Barney et al. is included in Appendix I. Several publications ${ }^{4-9}$ include discussions of the uranium-mill tailings problem and of the assessment of their radiological impact.

\section{SITE DESCRIPTION}

A descripticn of the inactive uranium-mill site near Lakeview, Oregon, and a history of the operations at this site are included in the Phase I engineering survey report (Appendix I) and only a brief summary of this information is presented here.

The Lakeview site, owned by Atlantic Richfield Company (ARCO), is located $3 \mathrm{~km}$ ( 1.9 miles) northwest of the city of Lakeview. An aerial photograph of the ite and surrounding area is shown in Fig. 1 . Two separate areas make up the tailings pile; one area covers approximately 


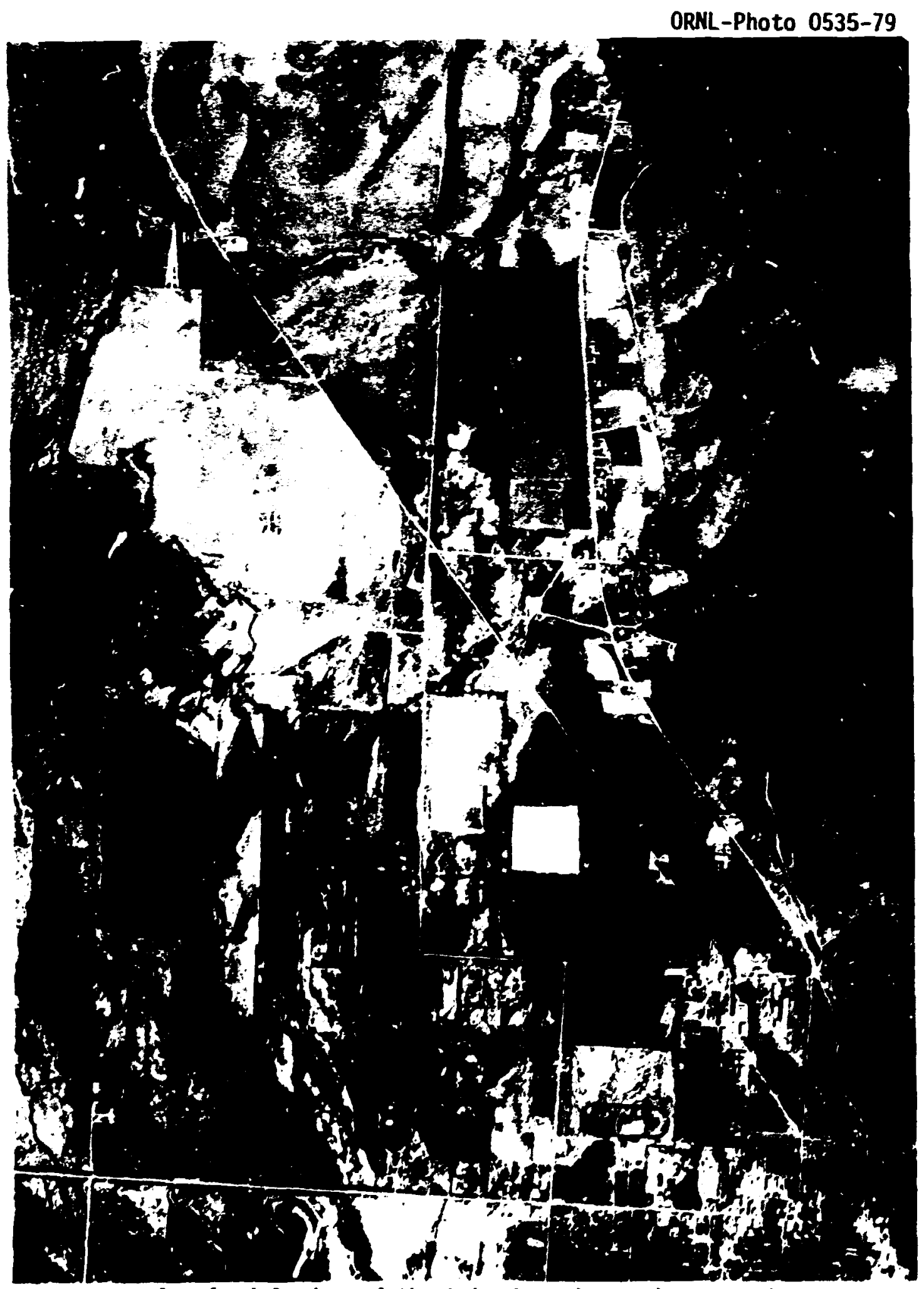

Fig. 1. Aerial view of the Lakeview site and surrounding area. Source: EG\&G, Inc. 
14 hectares ( 35 acres), whereas the second area covers 12 hectares ( 30 acres). The entire Lakeview site is described ${ }^{2}$ as covering an area of 104 hectares (258 acres) (Appendix I). The evaporation ponds cover in area of abuut 26 hectares (64 acres). ${ }^{2}$ Operation of the uranium mill lasted from 1958 to 1961. During this time, approximately 118,000 metric tens of ore containing an average $\mathrm{U}_{3} \mathrm{O}_{8}$ content of $0.15 \%$ were processed. The taiiings pile is estimated to have a theoretical concentration of ${ }^{226} \mathrm{Ra}$ of $\left.4 \hat{\imath}\right) \mathrm{pCi} / \mathrm{g}$ and to contain a total of $50 \mathrm{Ci}$ of this isotope (Appendix I).

Most of the mill buildings at this site were intact at the time of this survey. Atlantic Richfield is reported to have decontaminated the mill building and to have removed machinery and other salvageable iters from the site. The tailings pile was covered with soil to a depth of approximately 46 to $60 \mathrm{~cm}$ (18 to $24 \mathrm{in}$.). This cover supports a vigerous growth of regetation. The tailings pile is surrounded by a hogwire-type fence, and the entire site has a barbed wire fence around it. Evidence of wind erosion of the tailings pile was reported by CB\&DU. "

\section{SAMPLING TECHNIQUES AND RADIOLOGICAL MEASUREMENTS}

Sampling techniques, as well as equipinent and methods used for analyses of soil samples for radionuclices and for radiological monitoring, are describad in Appendix II. A description of the techniques used to analyze water samples is contained in Appendix III.

\section{RESULTS OF MEASUREMENTS}

Measurements were made at the Lakeview site to determine: (1) background external gamma radiation levels and background radionuclide concentrations in surface soil samples; (2) external gamma-ray exposure rates $1 \mathrm{~m}$ above the ground at the site; (3) radionuclide concentrations in surface or near-surface soil samples; (4) radionuclide concentrations in water samples; and (5) the subsurface distribution of ${ }^{226} \mathrm{Ra}$. Because of the short term of the survey, no attempts were made to measure the 
concentration of radon, radon jaughters, or other airborne radionuclides. Resjils of the various types of measurements are discussed in separate sections below.

\subsection{Background Radioactivity}

Knowlidge of background external gamma radiation levels and of background concentrations of radionuclides in the area surface soil is needed in order to evaluate the extent of spread of tailings from the sice and to provide data needed in implementing clean-up procedures if they are required.

Locations are shown in Fig. 2 where background measurements were made of external gamma-ray exposure rates $1 \mathrm{~m}$ above the ground and where surface : :oil samples were obtained for analysis. Details of the sample sites and the rs sults obtained are displayed in Table 1.

The data in Table 1 show a variation in measured values of the background ( amma-ray exposure raie $1 \mathrm{~m}$ above the ground from $\&$ to 19 $\mu \mathrm{R} / \mathrm{hr}$. The average value of $11 \mu \mathrm{P} / \mathrm{hr}$ corresponds to an annual background dose equivalent of 96 millirems. The average ${ }^{226}$ Ra concentration in surface soil samples is $0.8 \mathrm{pCi} / \mathrm{g}$. There is not a good correlation between the direct gamma-ray exposure rate above the ground and the ${ }^{226} \mathrm{Ra}$ concentration in surface soil, possibly due to the presence of other terrestrial radionjclides, failure to obtain representative soil samples, and poor statistics in gamma radiation measurements resulting from the small amount of activity in the samples.

\subsection{Direct Gamma-Ray Exposure Rates}

Measuremen's were made of direct gamma-ray exposure rates $1 \mathrm{~m}$ above the ground us:ng a glass-walled Geiger-Mueller (G-M) tube ("Phil") described in Appt.ndix II. These measurements were made at $46-m$ (50-yd) intervals. The data show exposure rates over the tailings pile ranging from 9 to $53 \mu R / h r$ with all average value of $16 \mu R / h r$ (Fig. 3). The range for the evaporation ponds is 2 to $24 \mu \mathrm{R} / \mathrm{hr}$ with an average of $10 \mu R / h r$. The average exposure rate in the nill area is $35 \mu R / h r$, with a maximum reading of $96 \mu \mathrm{R} / \mathrm{hr}$. 


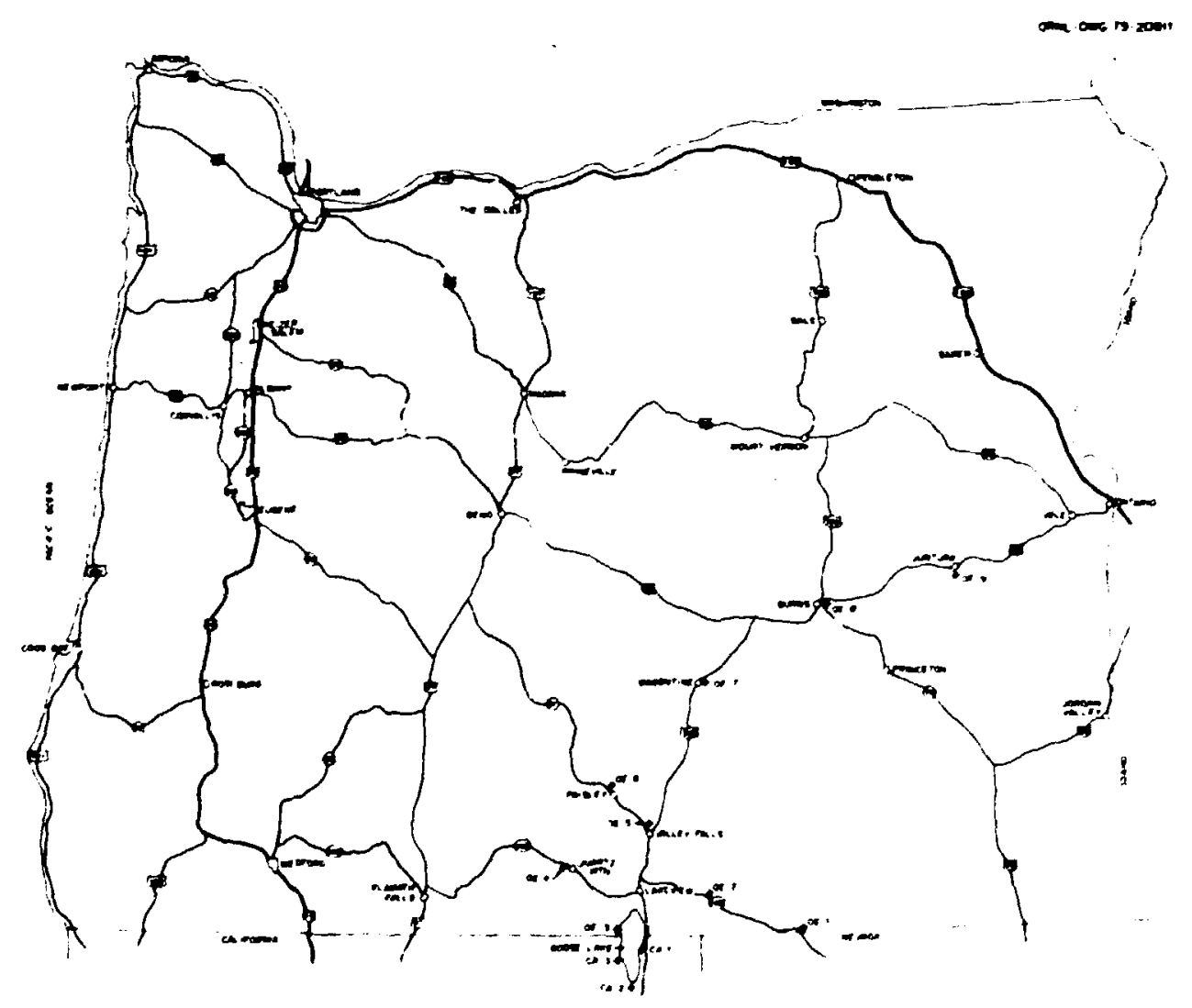

Fig. 2. Locations of background external gamma measurements and background surface soil samples. 
Table 1. Locations of background external gamma measurements and background surface soil samples around Lakeview, Oregon

\begin{tabular}{|c|c|c|c|c|c|}
\hline \multirow[b]{2}{*}{$\begin{array}{l}\text { Sample } \\
\text { point }\end{array}$} & \multirow[b]{2}{*}{ Location } & \multirow{2}{*}{$\begin{array}{c}\text { External y } \\
\text { exposure } \\
\text { rate }^{a} \\
(\mu R / h r)\end{array}$} & \multicolumn{3}{|c|}{$\begin{array}{c}\text { Nuclide concentration } \\
(\mathrm{pC} \mathrm{C} / \mathrm{g})\end{array}$} \\
\hline & & & $226 R a$ & 232 Th & $238 \mathrm{U}$ \\
\hline OE1 & Oregon and Utah border at nnrtheast side of Hwy 140 & 19 & 2.1 & 1.5 & 0.8 \\
\hline OE2 & Northside of Hwy $140 \sim 1.6 \mathrm{~km}$ & 10 & 0.2 & 0.5 & 0.2 \\
\hline $0 \mathrm{E3}$ & $0.8 \mathrm{~km} \mathrm{~N}$ of California border on $W$ side of Goose Lake & 13 & $b$ & 0.7 & 0.3 \\
\hline $0 \mathrm{E} 4$ & S side of Hwy $140 \sim 1.6 \mathrm{~km} \mathrm{~W}$ of Quartz Mountain & 8.3 & 0.4 & 0.4 & 0.2 \\
\hline $0 E 5$ & Intersection of Hwys 395 and 31 & 9.7 & 0.6 & 0.6 & 0.2 \\
\hline OE6 & $N$ side of Hwy 31 at west side of Paisley, Oregon & 9.5 & 0.8 & 0.7 & 0.4 \\
\hline OE7 & E side of Hwy 395 across hwy from Wagontire & 10 & 0.8 & 0.7 & 0.3 \\
\hline OE8 & $8 \mathrm{~km} E$ of Burns, Oregon on $S$ side of Hwy 20 & 12 & 1.0 & 0.9 & 0.4 \\
\hline OE9 & S side of Hwy $20 \mathrm{~W}$ of city limits of Junturo, Oregon & 8.2 & 0.6 & 0.5 & 0.2 \\
\hline C.A1 & $\begin{array}{l}\text { W side of US } 395 \text { at junction of Hwy } 395 \text { and County } \\
\text { Road } 46\end{array}$ & 9 & 1.3 & 0.8 & 0.5 \\
\hline CA2 & E side of Co. Rd. 48 S of Goose Lake & 11 & 0.8 & 0.6 & 0.4 \\
\hline \multirow[t]{2}{*}{ CA3 } & $\begin{array}{l}\text { E side of county road on } W \text { side of Goose Lake at } \\
\text { irowder Flats turn off }\end{array}$ & 11 & 0.2 & 0.3 & 0.1 \\
\hline & AVERAGE & 11 & 0.8 & 0.7 & 0.3 \\
\hline
\end{tabular}

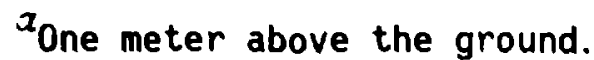

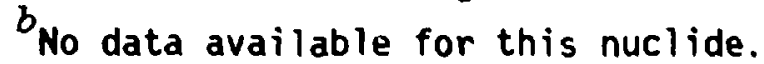


The data in fig. 3 show low exposure rates over the tailings pile and the evaroration ponds; there is no evidence of significant spread of contamination from either part of the site. The highest readings in the vicinity of the tailings pile were at the eastern edge of the pile $(53 \mu R / h r)$ and a few meters north of the pile ( $37 \mu R / h r)$. The exposure rate in the former mill area is moderately low but is higher than that existing in the areas of the tailings pile or evaporation ponds.

4.3 Concentration of ${ }^{225} R a$ in Surface Soil and Sediment Samples Analysis of soil and sediment samples for ${ }^{226} R a$ supplements the measurements of above-ground gamma rays in detecting the spread of uranium tailings or uraniun ore particles. Surface and near-surface suil and sediment samples were analyzed for ${ }^{226} \mathrm{Ra}$ by use of the technique and equipment described in Appendix 1I. Results are displayed in Table 2. Environmental sample locations are showr in Fig. 4, including the locations of water samples ciiscussed below. Soil and sediment sample locations are also described in Table 2.

It is evident from the data in Table 2 that surface contamination with ${ }^{226}$ Ra is low in the vicinity of the Lakeview tailings pile and the evaporation ponds, in agreement with the results of the gamma-ray exposure rate measurements discussed in the previous section. The dry-wash* samples show no evidence of significant movement of tailings particles by water erosion, and the surface soil samples indicate that wind erosion of the tailings pile has also not produced significant spread of contamination at this site. At each water sample location, a sampln of sediment was collected from the floor of the water body. The samples were analyzed according to the techniques described in Appendix II. Results are displayed in Table 2.

${ }^{\star} A$ dry-wash area may be described as an area of apparent surface water drainage away from a tailings pile. In these areas, samples were collected on the surface and at $15 \mathrm{~cm}$ ( 6 in.) below the surface at regular interials along this crainage path. 
ORNL-Photo 5154-79C

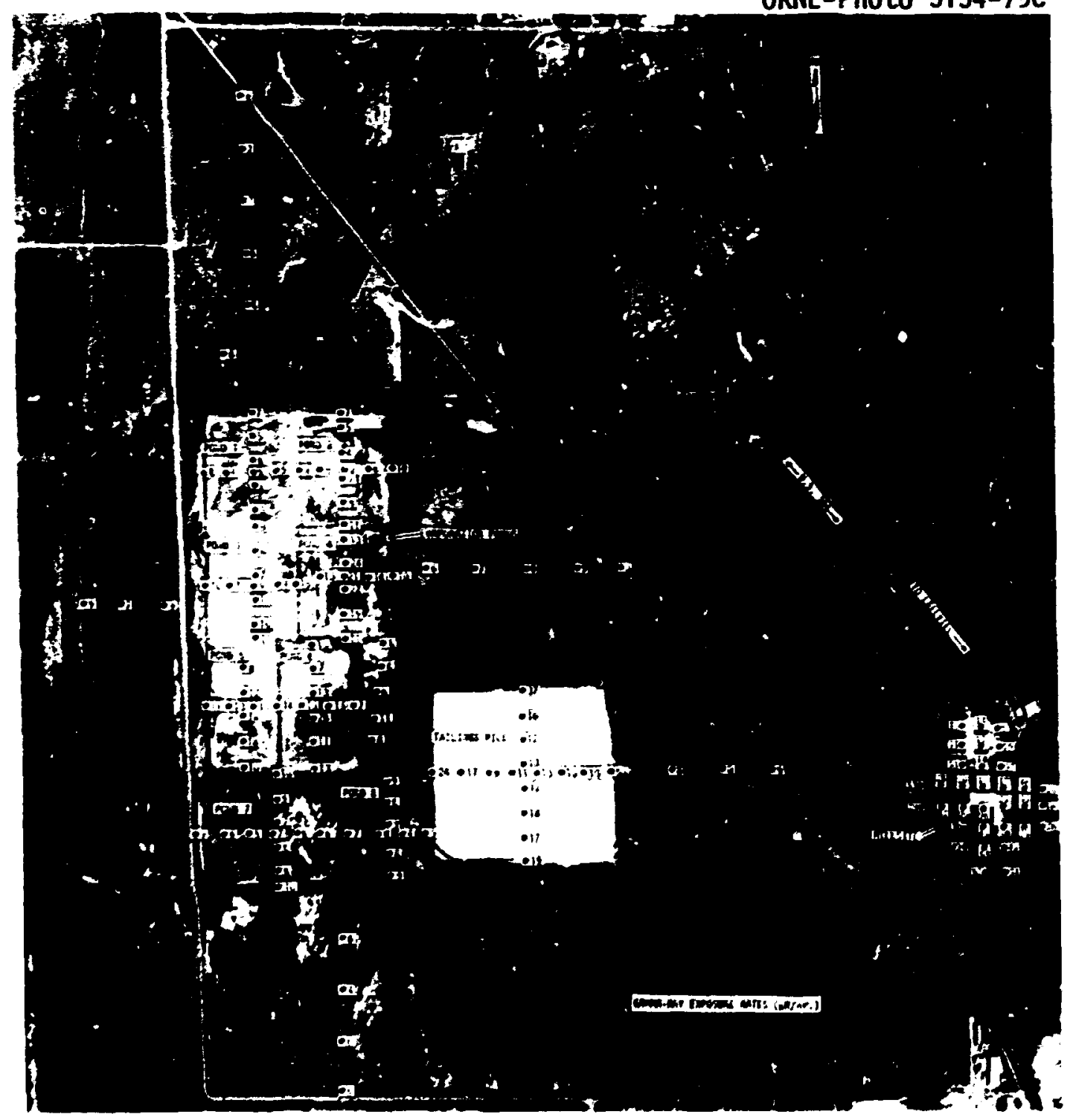

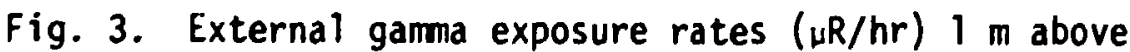
the ground at the Lakeview site. Original photo by EG\&G, Inc. 
Table 2. Concentration of ${ }^{225}$ Ra and ${ }^{232}$ Th in surfares $5 \cdot i 1$ and sediment samples at the Lakeview $s:$

\begin{tabular}{|c|c|c|c|}
\hline \multirow{2}{*}{$\begin{array}{c}\text { Sample } \\
\text { designation }\end{array}$} & \multirow[b]{2}{*}{ Sample location and description } & \multicolumn{2}{|c|}{ 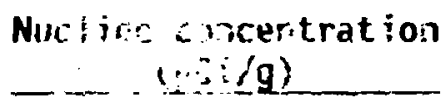 } \\
\hline & & 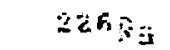 & $2.32 \mathrm{Th}$ \\
\hline ZDW1 & $\begin{array}{l}\text { Surface sediment from dry wash in } \\
\text { a ditch running } 5 \text { at } S \text { end of tailings } \\
\text { pile (TP) } \sim 3 \mathrm{~m}(10 \mathrm{ft}) \mathrm{S} \text { of TP fence }\end{array}$ & $0^{7}$ & $\pi$ \\
\hline ZDW2 & $\begin{array}{l}\text { Sediment from same location as } 20 W 1 \\
\text { but } 15 \mathrm{~cm} \text { below surface }\end{array}$ & 0.5 & 0.5 \\
\hline ZDW3 & $\begin{array}{l}\text { Surface sediment fron dry wash in a } \\
\text { ditch running south at } S \text { end of TP } \\
91 \mathrm{~m}(100 \mathrm{yo}) \mathrm{S} \text { of fence }\end{array}$ & 0.5 & 0.5 \\
\hline ZDW4 & $\begin{array}{l}\text { Sediment from same location as ZDW3 } \\
\text { but } 15 \mathrm{~cm} \text { below surface }\end{array}$ & 0.5 & 0.5 \\
\hline 20W5 & $\begin{array}{l}\text { Surface sediment from dry wash } S \text { of } \\
\text { TP fence }\end{array}$ & 1.1 & 0.9 \\
\hline ZDW6 & $\begin{array}{l}\text { Sediment from same location as ZDW5 } \\
\text { but } 15 \mathrm{~cm} \text { beiow surface }\end{array}$ & 0.6 & 0.5 \\
\hline ZDW7 & $\begin{array}{l}\text { Surface sediment from dry wash } 136 \mathrm{~m} \\
(150 \text { yd) } \mathrm{S} \text { of TP }\end{array}$ & 1.0 & 0.7 \\
\hline ZOW8 & $\begin{array}{l}\text { Surface sediment from same location } \\
\text { as } 20 W 7 \text { but } 15 \mathrm{~cm} \text { below surface }\end{array}$ & 0.5 & 0.5 \\
\hline Low9 & $\begin{array}{l}\text { Surface sediment from dry wash in a } \\
\text { ditch northeast corner of Pond } 9\end{array}$ & 0.9 & 0.4 \\
\hline ZDW10 & $\begin{array}{l}\text { Sediment from same location as ZDW9 } \\
\text { but } 15 \mathrm{~cm} \text { below surface }\end{array}$ & 0.5 & 0.5 \\
\hline 20W/11 & $\begin{array}{l}\text { Sediment from surface dry wash in a } \\
\text { ditch at logging road from NE corner } \\
\text { of TP }\end{array}$ & 0.6 & 0.6 \\
\hline ZDW12 & $\begin{array}{l}\text { Sediment from tie same location as 20W11 } \\
\text { but } 15 \mathrm{~cm} \text { below surface }\end{array}$ & 0.6 & 0.6 \\
\hline
\end{tabular}


Table 2. (continued)

\begin{tabular}{|c|c|c|c|}
\hline \multirow{2}{*}{$\begin{array}{c}\text { Sample } \\
\text { designation }\end{array}$} & \multirow[b]{2}{*}{ Sample iocation and description } & \multicolumn{2}{|c|}{$\begin{array}{l}\text { Nuclide concentration } \\
(\mathrm{pCi} / \mathrm{g})\end{array}$} \\
\hline & & ${ }^{226} \mathrm{Ra}$ & ${ }^{232} \mathrm{Th}$ \\
\hline ZDW13 & $\begin{array}{l}\text { Surface sediment from dry wash in } \\
\text { a ditch } 90 \mathrm{~m} \text { of logging road from } \\
\text { NE corner of TP }\end{array}$ & 0.5 & 0.5 \\
\hline 20W14 & $\begin{array}{l}\text { Sediment from same location as } \mathrm{ZOH} 13 \\
\text { but } 15 \mathrm{~cm} \text { below surface }\end{array}$ & 0.4 & 0.4 \\
\hline Z200S & $\begin{array}{l}\text { Surface so, i } 182 \mathrm{~m} \text { ( } 200 \mathrm{yd}) \mathrm{S} \text { from } \\
\text { base of evaporated pond }\end{array}$ & 09 & $a$ \\
\hline $2400 S$ & $\begin{array}{l}\text { Surface soil } 365 \mathrm{~m} \text { ( } 400 \mathrm{yd}) \mathrm{S} \text { from } \\
\text { base of evaporation pond }\end{array}$ & 0.5 & 0.4 \\
\hline Z200N & $\begin{array}{l}\text { Surface soil } 182 \mathrm{~m}(200 \mathrm{yd}) \mathrm{N} \text { from } \\
\text { base of evaporation ponds }\end{array}$ & 0.3 & 2.0 \\
\hline Z400N & $\begin{array}{l}\text { Surface soil } 365 \mathrm{~m} \text { ( } 400 \mathrm{yd}) \mathrm{N} \text { 'rom } \\
\text { base of evaporation ponds }\end{array}$ & 0.3 & 0.2 \\
\hline Z600N & $\begin{array}{l}\text { Surface soil } 550 \mathrm{~m} \text { ( } 600 \mathrm{yd}) \mathrm{N} \text { from } \\
\text { base of evaporation ponds }\end{array}$ & 0.4 & 0.3 \\
\hline Z400E & Surface soil $365 \mathrm{~m}(400 \mathrm{yd}) \mathrm{E}$ of TP & 1.0 & 0.5 \\
\hline Z200W & Surface oii $183 \mathrm{~m}(200 \mathrm{yd})$ W of TP & 0.5 & 0.6 \\
\hline ZWS1 & $\begin{array}{l}\text { Water sediment from a stream } 820 \mathrm{~m} \\
(900 \mathrm{yd}, N \text { of TP }\end{array}$ & 0.66 & $a$ \\
\hline ZWS2 & $\begin{array}{l}\text { Sediment from a pool at } N \text { end of } \\
\text { evaporated pond }\end{array}$ & $a$ & $a$ \\
\hline ZWS3 & $\begin{array}{l}\text { Sediment from runoff of pool } \mathrm{N} \text { of } \\
\text { evaporated pond }\end{array}$ & 0.80 & $a$ \\
\hline ZWS4 & $\begin{array}{l}\text { Sediment from a stream } S \text { of eyaporated } \\
\text { pond }\end{array}$ & 0.50 & 0.56 \\
\hline IWS5 & $\begin{array}{l}\text { Sediment sample from ditch in field } \\
S \text { of } T P\end{array}$ & 0.51 & 0.50 \\
\hline
\end{tabular}

$a_{\text {No data available for this nuclide. }}$ 


\subsection{Radiochenical Analysis of Water Samples}

Water samples were obtained at eiglit locations shown in Fig. 4. These samples were analyzed using the technique described in Appendix III. The results are displayed in Table 3, which also contains descriptions of sample locations. The concentration of radium in each of the samples is below the EPA interim stancard for orinking water (5.0 pCi/liter for $\left.{ }^{226} \mathrm{Ra}+{ }^{228} \mathrm{Ra}\right) .10$

\subsection{S'sbsurface Distribution of ${ }^{226} R a$ in Sn:? and Tailings}

Holes weie drilled at the ocations shown in Fig. 5 . Measurements of ganaa rays as a function of depth were made by FB\&DU personnel using the apparatus described in Appendix II. Since the subsurface gama rays are due frimarily to ${ }^{226} \mathrm{Ra}$ and severa! of its daughters, it is possible to calibrate the instrument and. thus, to convert the gamma-ray measurements to concentration of ${ }^{226} \mathrm{Ra}$. A conversion factor may be develof =o by compraring gama-ray measurements with iocal ${ }^{226}$ Ra concentration in holes where both quantities are known. Holes at this site were drilled with hand augers, and no soil samples were obtained from these holes for analysis. Also, polyvinyl chloride (PVC) pipe was not used in the holes during the gama radiation measurements so there is doubt as to the validity of the above-mentioned conversion.* The results of the calculation of subsurface distribution of ${ }^{226} R a$ are summarized in Table 4 instead of presented in the graphical form used in other reports in this series.

The calculated ${ }^{226}$ Ra concentrations in Table 4 show a few values at the surface around $15 \mathrm{pCi} / \mathrm{g}$; but, at the $0.6-\mathrm{m}$ depth and bolow, few measurements are significantly above the background level. Although litt!e significance should be attached to the absolute values of the numbers in Table 4, the data do tend to confirm the indications from

\footnotetext{
*Normally. such a pipe, sealed at one end, is used as a hole liner and the gamma-ray hole logger is lowered into the pipe. This is to insure dry conditions.
} 


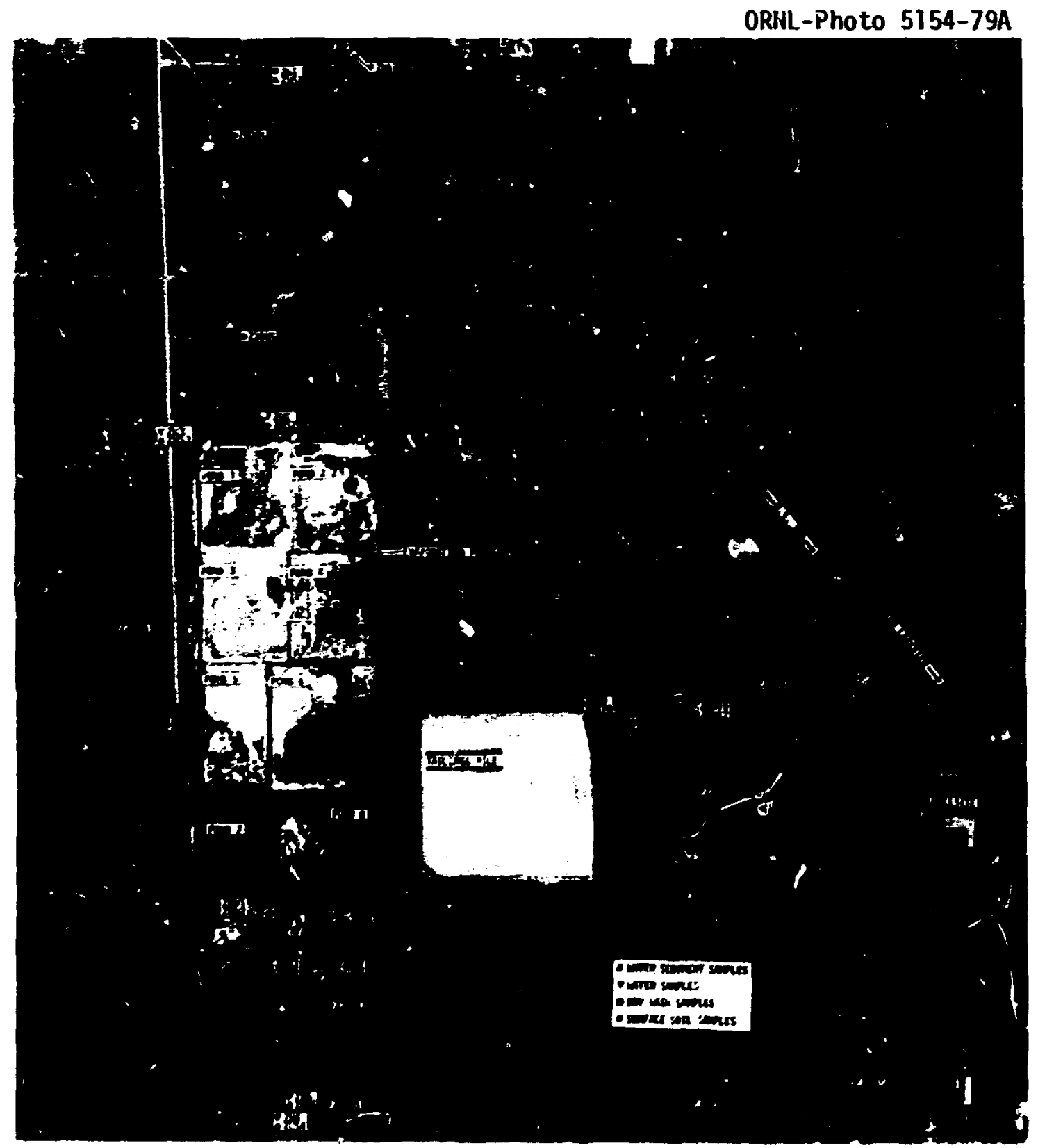

Fig. 4. Locations and identifications of environmental samples. Original photo by EG\&G, Inc. 
Table 3. Concentration of ${ }^{226} \mathrm{Ra}$ in water samples

\begin{tabular}{|c|c|c|}
\hline $\begin{array}{c}\text { Sample } \\
\text { designation }\end{array}$ & Sample location and description & $\begin{array}{c}\text { Concentration } \\
\text { of } 226 \mathrm{Ra} \\
(\mathrm{pCi} / \mathrm{itcr})\end{array}$ \\
\hline$Z \mathbf{Z l}$ & $\begin{array}{l}\text { Water from a stream } 820 \mathrm{~m}(900 \mathrm{yd}) \\
N \text { of tailings pile (TP) }\end{array}$ & 0.03 \\
\hline ZWZ & $\begin{array}{l}\text { Water from pool at } N \text { end of evaporated } \\
\text { pond }\end{array}$ & 0.07 \\
\hline ZW3 & $\begin{array}{l}\text { Water from runoff of pool } N \text { of } \\
\text { evaporated pond }\end{array}$ & 0.006 \\
\hline ZW4 & Water from stream $S$ of evaporated pond & 0.004 \\
\hline ZW5 & Water in ditch in field $S$ of TP & 0.05 \\
\hline $2 W 6^{a}$ & $\begin{array}{l}\text { Water from house we } 11 \sim 0.8 \mathrm{~km} \mathrm{~N} \text { of } \\
\text { evaporated pond }\end{array}$ & 0.02 \\
\hline$Z W 7^{a}$ & Water from house well $\sim 1.0 \mathrm{~km}$ SE of TP & 0.03 \\
\hline $2 W B^{a}$ & Water from house well $\sim 0.8 \mathrm{~km} \mathrm{SW}$ of TP & 0.06 \\
\hline
\end{tabular}

${ }^{2}$ ZW6, 7, and 8 were taken from wells that are sampled by the Oregon State Health Department. 


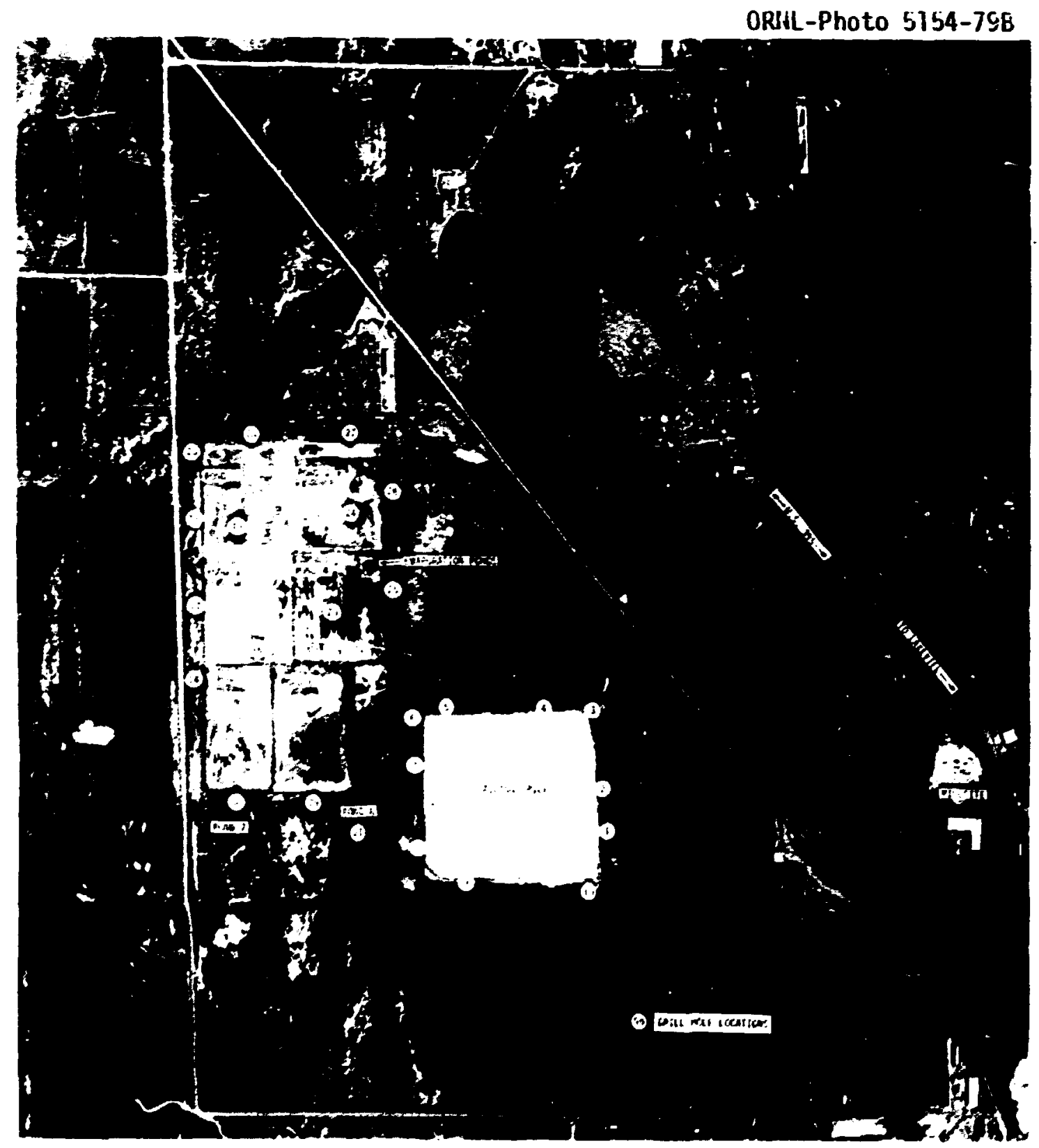

Fig. 5. Locations of holes drilled at the Lakeview site. Original photo by EG\&G, Inc. 
Table 4. Calculated concentrations of ${ }^{226} \mathrm{Ra}(\mathrm{pC}: / \mathrm{g})$ as a function of depth in auger holes at the Lakeview site

\begin{tabular}{|c|c|c|c|c|c|c|c|c|}
\hline \multirow[b]{2}{*}{ Hole } & \multicolumn{8}{|c|}{ Depth below surface (m) } \\
\hline & 0 & 0.15 & 0.3 & 0.45 & 0.6 & 0.76 & 0.91 & 1.07 \\
\hline 1 & 5 & & 2 & 6 & & & & \\
\hline 2 & 5 & $<1$ & $<1$ & & & & & \\
\hline 3 & 8 & & 2 & & 1 & 1 & & \\
\hline 4 & 14 & & $<1$ & & 1 & & & \\
\hline 5 & 4 & & $<1$ & & 3 & 7 & & \\
\hline 6 & 4 & & 4 & & 1 & & & \\
\hline 7 & 3 & & 5 & & 3 & 4 & & \\
\hline 8 & 4 & & 7 & & 6 & $<1$ & & \\
\hline 9 & 6 & & $<1$ & & 2 & 4 & & \\
\hline 10 & 3 & & 1 & & 3 & $<1$ & & \\
\hline 11 & & 7 & & 1 & & $<1$ & & \\
\hline 12 & 16 & & 4 & & 2 & & 10 & \\
\hline 13 & 15 & & 5 & & 2 & & $<1$ & \\
\hline 14 & $<1$ & & $<1$ & & 3 & 1 & & \\
\hline 15 & 7 & & 3 & & 4 & 4 & & \\
\hline 16 & 16 & & 2 & & 2 & & 2 & $<1$ \\
\hline 17 & 2 & & 2 & & 4 & & $<1$ & \\
\hline 18 & 3 & & $<1$ & & $<1$ & & 2 & \\
\hline 19 & 6 & & 3 & & 2 & & 2 & 4 \\
\hline 20 & 4 & & 2 & & $\mathrm{kl}$ & & $<1$ & \\
\hline 21 & $<1$ & & 2 & & 17 & & $<1$ & \\
\hline 22 & 5 & & 3 & & 5 & $<1$ & & \\
\hline 23 & 8 & & 4 & & 5 & & $<1$ & \\
\hline 24 & 5 & & 5 & & 4 & & $<1$ & $<1$ \\
\hline 25 & $<1$ & & 3 & & $k_{1}$ & & 4 & \\
\hline 26 & 4 & & $<1$ & & $<1$ & & 2 & \\
\hline 27 & 3 & & $<i$ & & $<1$ & & $<1$ & \\
\hline 28 & 3 & & $<1$ & & 2 & & 3 & \\
\hline 29 & 2 & & 3 & & $<1$ & & $<1$ & \\
\hline 30 & 4 & & 1 & & 2 & & 2 & \\
\hline
\end{tabular}


both analysis of surface soil samples and external gama-ray measurements that a low level of contamination is present at this site.

Three soil samples were removed from a $0.5-\mathrm{m}$-deep hole $\mathrm{d}$.g by hand near the southeast corner of the evaporation pond area and near FB\&DU hole 22 (Fig. 5). The results obtained fron the analysis of these samples, using the technique described in Appendix II, are compared in Table 5 with the calculated ${ }^{226}$ Ra concentration in the nearby monitored hole (Table 4, hole 22). The results of this comparison are in reasonably good agreement.

\section{SUMMARY}

The inactive uraniun-mill site at Lakeview, Oregon, covers an area of approximately 104 hectares (258 acres), of which the tailings pile occupies 12 hectares ( 30 acres) in one place and 14 hectares ( 35 acres) elsewhere and the evaporation ponds about 26 hectares (64 acres). The tailings pile contains 118,000 metric tons of material with an estimaied ${ }^{226} \mathrm{Ra}$ inventory of $50 \mathrm{Ci}$. There is an earth cover 46 to $60 \mathrm{~cm}$ (18 to 24 in.) trick, and it has a good vegetation cover. The gamma-ray exposure rate measurements and measured concentrations of ${ }^{226} \mathrm{Ra}$ in surface soil and sediment samples around the cililings pile and evaporation ponds, as well as the calculated ${ }^{226} \mathrm{Ra}$ concentrations in shallow auger holes, show little evidence of spread of tailings. The average gammaray exposure rate over the tailings pile is $16 \mu \mathrm{R} / \mathrm{hr}$, and the corresponding figure for the evaporation fonds is $10 \mu \mathrm{R} / \mathrm{hr}$. The latter figure is near the average background exposure rate for the area. The average exposure rate in the former mill area is $35 \mu \mathrm{R} / \mathrm{hr}$.

The ${ }^{226}$ Ra concentration in most surface soil and sediment samples is at or below the average background valuse for the region $(0.8 \mathrm{pCi} / \mathrm{g})$. The ${ }^{226}$ Ra concentration in a shallow (0.5-m deep) hole dug in one of the evaporation ponds ranged from $4.1 \mathrm{pCi} / \mathrm{g}$ at the surface to the background level at the botton of the hole. 
Table 5. Comparison of measured and estimated concentrations of ${ }^{226} \mathrm{Ra}$ in hand-dug hole near hole 22

\begin{tabular}{cccc}
$\begin{array}{c}\text { Sampla } \\
\text { designation }\end{array}$ & Depth in meters & \multicolumn{2}{c}{$\begin{array}{c}\text { Concentration of. }{ }^{226}{ }^{26} \\
(\mathrm{pCi} / \mathrm{g})\end{array}$} \\
\cline { 3 - 4 } $\mathrm{Z4Cl}$ & 0.15 & 4.1 & 5 \\
$\mathrm{Z4C2}$ & 0.30 & 1.9 & 3 \\
$\mathrm{Z4C3}$ & 0.46 & 1.0 & $a$ \\
\hline
\end{tabular}

$a_{\text {No gamma measurement available. }}$ 
We conclude that, because or the comparatively low s untamination level at this site and the apparently successful starilization of the tailings, potential health effects of the tailings are likely to be small. 


\section{REFERENCES}

1. F. F. Haywood, W. P. Goldsmith, P. T. Perdue, H. F. Fox, and H. H. Shinpaugh, Assessment of Radiological Impact of the Inactive UnanizmMill mailings Pile ai Salt Lake City, Utah, ORNL/TM-5251 (November 1977).

2. Ford, Bacon and Davis Utah Inc., Phase II-Title I, Engineering Assessment of Inactive Uranizn Mill Tailings, Lakeview Site, Lakeview, Oregon, GJT-18 (Lecember 1977).

3. R. L. Douglas and J. M. Hans, Jr., Gama Radiation Surveys at Inactive Uranium Milz Sites, Technical Note ORP/LV-75-5 (August 1975).

4. U. S. Atomic Energy Commission, Environmental Survey of the Uranizm Fuez Cycle, WASH-1248, (Aprit 1974).

5. U. S. Environmental Protection Agency, Environmental Analysis of the Uraniun Fuel Cycle, Part I. Fuel S'spply, PB-235804 (October 1973).

6. M. B. Sears, R. E. Bianco, R. C. Dahlman, G. S. Hill, A. D. Ryon, and J. P. Witherspoon, Correzation of Radioactive Waste Treatment Costs and the Environmental Impact of Waste Effluents in the Nuclear Fuel Cycie for Use in Establishing "As-Low-As-Practicable" GuidesMilling of Uranizon Ores, ORNL-TM-4903, Vol. I (May 1975).

7. J. J. Swift, J. M. Hardin, and H. W. Calley, Potential Radiological Impact of Airborme Releases and Direct Gama Radiation to Individuals Living Near Inactive Uranium Mill Tailings Piles, EPA-520/1-76-001 (January 1976).

8. K. J. Schiager, "Analysis of Radiation Exposures on or Near Uranium Mill Tailings Piles," Radiol. Data Rep. 15, 411-25 (1974).

9. W. A. Goldsmith, "Radiological Aspccts of Inactive Uranium-Milling Sites: An Overview," Nucl. Saf. 17(6),722-32 (1976).

10. Code of Federal Regulatio", Tit?e 40, Part 141 (Ju1y 9, 1976). 


\section{APPENDIX I}

PHASE I

Report on Conditions of Uranium Millsite and Tailings at Lakeview, Oregon

Site visited May 9, 1974 by

Robert F. Barney, Lucius Pitkin, Inc. (Contractor to USAEC), Grand Junction, Colorado, William L. Lappenbusch, Environmental Protection Agency, Region $X$, Seattle, Washington, George A. Boysen, Environmental Protection Agency, Office of Radiation Programs, Las Vegas, Nevada, George T. Toombs, State Heaith Division, Portland, Oregon.

This Phase I site investigation was conducted under a cooperative agreement among the Atomic Energy Commission, the Environmental Protection Agency and the State of Oregon. The report, prepared by Lucius Pitkin, Inc., under AEC Contract AT(05-1)912, is reproduced directly from the best available copy with color photographs attached to the original report changed to black and white. 
REPOAT ON CONDITIONS OF URAIIUA MIISITE AND TATLDGS

AT LAKEVIEN, ORECON

\section{Introduction}

Pertinent information has been accumulated from available records of the $A B C$, EPA, the states and companies involved. An on-site visit was made to nute current conditions, inciuding the millsite and the tailings disposal area, proximity to populated and industrialized areas, present ownership, and whether a need for corrective action exists. It is intended that this report will serve as a basis for determining the necessity of a detailed engineering assessment (Phase II).

This report on the site at Lakeview, Oregon, was prepared jointly by the $A E C$, the EPA, and the Oregun State Health Division.

\section{Summary and Conclusions}

Lakeview Mining Company built and operated the mill from December 1958 to December 1960. The plant and site are now owned by Atlantic Richfield Company (APCO) nlthouph there was a chain of ownership in between. During the period of operation 130,000 tons of ore averaping 0.15 percent $\mathrm{U}_{3} \mathrm{O}_{8}$ were treated. The 171 tons of uranium oxide produced was sold to the $8 \mathrm{ac}$.

The tai ings are contained in one large pile covering about 35 acres. There is no cover or vegetation on the tailings pile. A swil water pond on one corner is present during the rainy season. A compacted dike has been constructed out of nearby topsoil around the pile. The dike supports - fair amount of vegetation.

A gawma survey has been made in Lakeview and the vicinity of the millsite, but no contamination of tailiros was determined. In nddition, the State of oregon has collerted and analyzad samples of water, soil and vegetation from around the site.

At present, the main health concern appears to be the wind and water erosion of the uncovered and unvegetnted tailings pile.

As a result of the site visit and review of the available information, it is concluded that a detailed further study of the site is not wnrranted. The following actions should be recommended to the owner of the property:

I. Repair and strengthen the fence around the site perimeter and strengthen the entrance barricade. Post the fence with no trespasing, and radiation signs. 
II. Stabilize the tailings area to prevent wind and water erosion.

21. is understond that since the site visit ARo has begun millsite clennki, tailings stabilizntion and fencing and posting in urcorance $w i t h$ plans opproved by the State.

Location

The property, consisting of 283 acres as show in Figure 1 , and the aerial pbotograph, is loceted in southern Oregon, in Lake County about two ailes northrest of the city of Lakeview. The elevation is about 4,750 feet above sea level with pountains to the east rising to over 6,700 feet. The site covers parts of Sections 3,4, 9, and 10, Townchip 39 South, Range 20 East, Willasette Principal Meridian at $42^{\circ} 12^{\prime} 43^{\prime \prime}$ Iorth latitude and $120^{\circ} 22^{\prime} 09^{\prime \prime}$ West longitude.

onership

The millsite and tailings pile are amed by the Atlantic Richfield Company with operating offices in Denver, Coiorado.

The operational owner of the property consisted of the same ownership as the Gunnison Mining Coupany of Gumison, Colcrado. In 1961 both Lakeview and Gunnison were acquired by Kerr-McGee ofl Industries through its subsidiary, Kermac Nuclear Fuels Corporation. The property has had $f^{z}$ ve different omers between 1960 and the acquisition by ARCO in 1968 .

\section{Process Description}

The Lakeview mill treated ores from the wite King and Lucky Lass wines of southern Lake county, oregon. Ore vas fros silicified volcanic rocks in the White King orebody in which uranium inineral was found as the arsenate, novacekite. In the lucky Isess ore, the uranius occurred as autunite. The mill operated with a rated capacity of 210 tons of ore per day.

The Iakeview process included acid leaching and solvent extraction and was similer to the Gunnison operation. if

Present Mllsite

Ho coupany personnel accompanied the survey team. Keys for the gate and bulldings were obtalned fron the sheriff's office. There is isttle control of the aite other than the sbiriff and occasional checks and vists by ARCO and periodic Visic; by state representatives. 


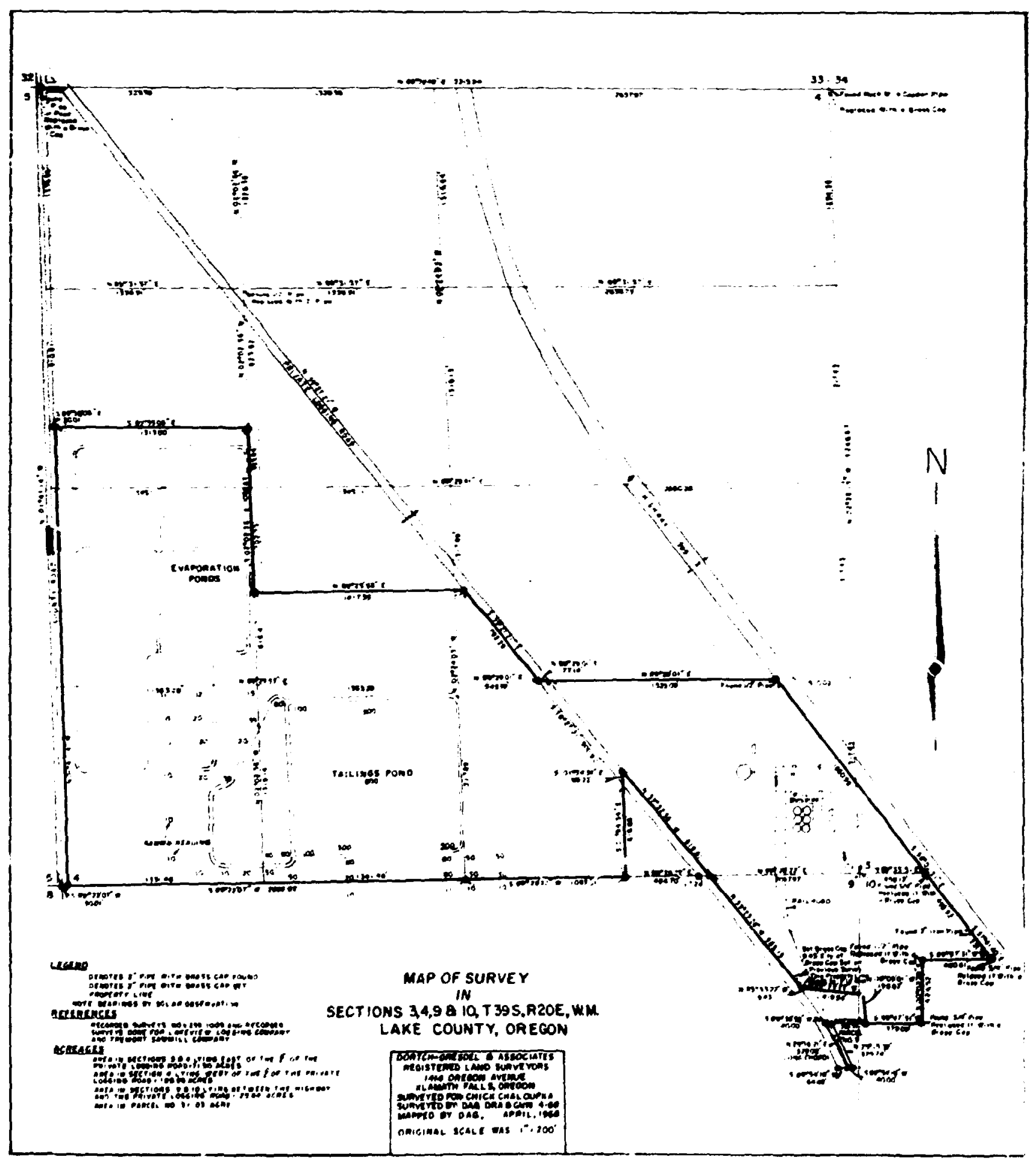

Figure 1. Milsite Layout and Game Survey of Tallings Aren 
Most of the mill buildings are intect, as shown in Fhotogrephs 1, 2 and 3 , but some of the will equipment has been resored. The fence around the dill is in good condition, but the gate needs to be better secured.

The 35 acre tallings pile and nearby evaporation ponds (Photograph 4) are show on Figure 1. Dikes construsted of topsoil surround the tailings piles and poods and support a good regetation cover in nost places. (Fhotograph 5). The tailings pile dike is about five reet high, but has been breached at the southesst corner. There is no sorer on the 1-1/2 to orer 2 feet thick tailings aterial exiept in the northwest corner where there vas sone water cover due to rain during the inspection visit. (Photograph 6). There is evidence of mtorcycle activity on the tailings as shown in Fhotograph 7 . The tailings are fine and dry in most I.laces and have a tendency to aigrate out of the diked area by wind erosion.

\section{Bavironmentel Considerations}

On the basis of processine 130,000 tons of ore that areraged 0.15 percent $\mathrm{U}_{3} \mathrm{O}_{\mathrm{B}}$, and assuning secular equilibrium the theoretical concentration of Ra-226 in the tailings is about 420 pCI per gram of tailings. The total Ra-226 inventory in the tailings pile is estimated at 50 curies.

Gamen measurements for the tailings pond orea nre shown in Figure 1 und for the mill area in Figure 2.

Ar. environmental ganme radiation survey was conducted in Lakeview, oregon, by EPA in cooperation with the State of Oregon. 2/ s.s a first step, 1,345 structures were scanned by an ABC truck mounted mobile game unit under contract to EPA and 18 anomalies (locations with gamm levels above background) were located. After the gama scan was comple'ved, a field survey team checked the 18 locations to determine what caused the anomaly. At six of these locations no gemma activity greater than beckground could be found by the field team. At two locations increased gomm rediation was caused by ore samples or spilled ore located on the property. At the 10 remaining locations slightly elevatcl garm levels were associated wi in brick, stone, gravel, or pavement materlal. No tailings naterials vere detected at any location. At the time o? this survey, the field team made a detailed gama survey of the millsite and tailings pile. The results of this survey are included in Figures 1 and 2. Later it was determned that the houses in the vicinity of the tailings pile hod not been scanned since they are north of Lakeview and separated from the town itself. An EPA and State of Oregon field team returned to Lakeview to do ganns surveys of these locations. Twenty-six locations vere surveyed and no tallings were found at any of these locations. Sowe of these locations were down-wind of the tallings pile and no wind-blown tailings could be detected outside of the structures with the survey meters. In addition, a motel in Lakeview was checked. A gann reading of $25 \mathrm{uR} / \mathrm{hr}$ was found at the fence behind the motel. The source of the gam radiation could not be determined. At the tive of this survey (October 1973) a detalled 


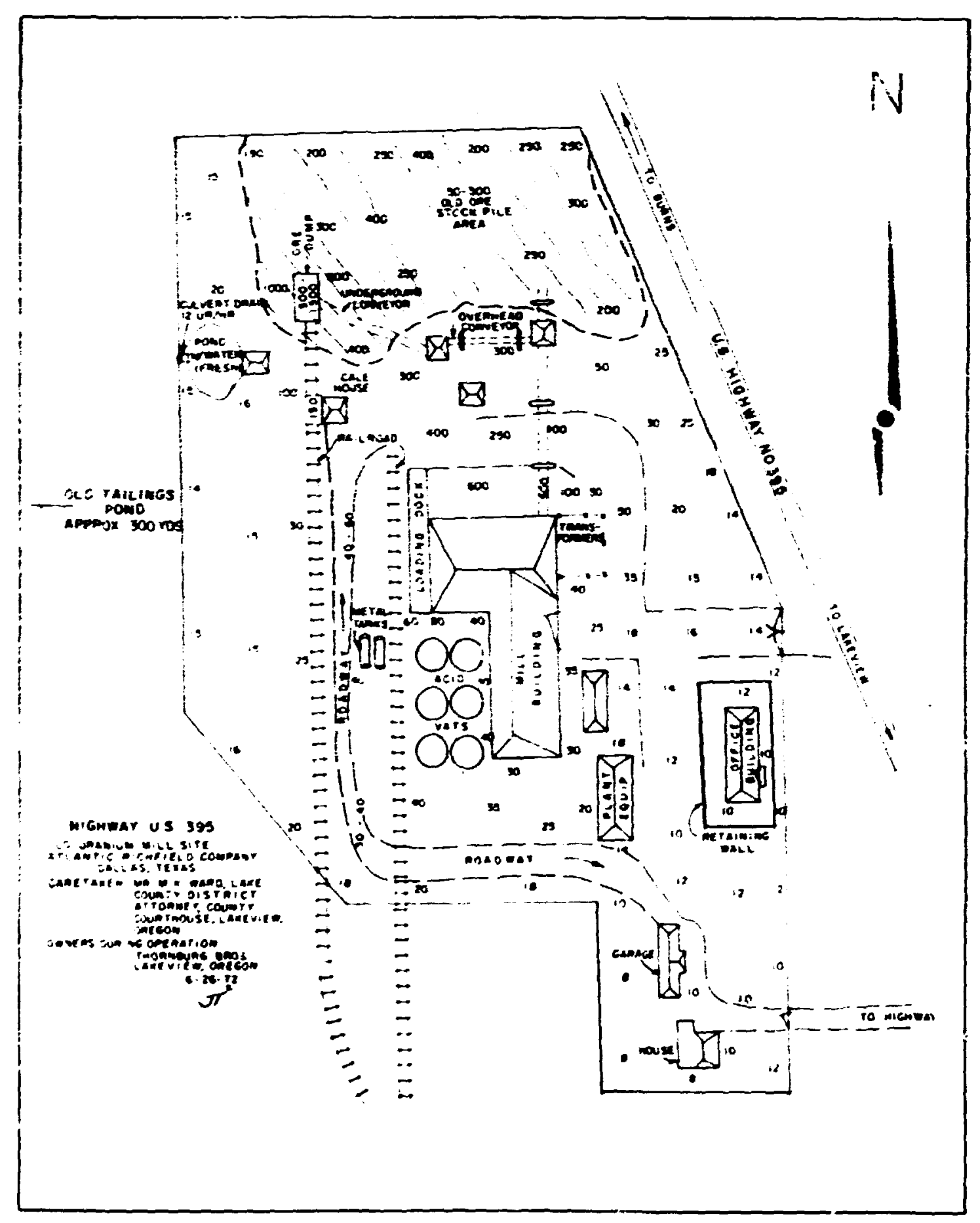

Pigure 2. Mill inyout and Game Survey of Mall Area 
gann surrey ras conducted around the site barders of the tailings pile area. The results shored that nost of the radiation at the border (as high as $95 \mathrm{uR} / \mathrm{hr}$ ) was apparently caused by "shine" fron the piie itself and not from any tailings deposited intside the borders. A sall anomt of tailings could have been deposited in this area outside the borders of the site and not be detected by the survey instrunents. To determine this soil samples vere collected. The results of the analysis of these saples are not available at this tine. A vater saple collected from the strean that flows north of the evaporation ponds contained 0.27 pCI per liter of Ra-226. The State of Oregon collected saples of vater, soil, and vegetation from aruind the site and these saples are presently beirg annlyzed by the State. At the tine of the second survey by ERA, air samples for the determination of radon daughter levels were taken in two houes about one mile down-wind from the center of the tailings pile. These samples shoved that radon daughter levels were at background levels during this sampling period. 3 /

Lakevied appears to be a stable comaity of about 2,700 population, according to the 1970 census and being within two ile radius of the tailings. Very few new comercial buildings or howes were noted. Most of the land between the tailings ponds and bouses is pasture land.

The main industry is logging. The sawill and assoclated buildings fore the north border of town. Fone of these bulldings appeared to be very new. One of the significant industrial buildings is the partially cannibalized, non-operating urenium will building. Buployment at this facility, not including mining ( 25 miles away), was less than 100 peopie when it was operating. Refer to photographs which show the present millsite.

\section{Meteorology}

Lakeview is in a northern area with cold winters, considerable snow and moderate rainfall. Winds are mostly from the south and wind speeds are generally quite light at less than 15 mph 85 percent of the time. occasionally there are gusts up to a maximum of about $75 \mathrm{mph}$. Freeze period is early November to late April as an average. The average annunl precipitation is about 14 inches. Relative humidity averages about 58 percent.

\section{Hydrology}

The tailings pile is located in a faut-block besin in the sem-desert region of south-central oregon. Ground vater and surface water drainage Is southward to Goose Lake. The lake has not overflowed since 1881 and diversion of inflow for Irrigation makes overflow again unlikely. Overflow elevation is about 35 feet lower then the tailings pond, so that even if the lake fllled sufriciently to cause overflow, the tailings will not be inundated. 
The three largest input creeks to Goose Lake do not pose a flood problem to the tailings pond. There is an unnamed ephemeral otrean in Hawersley Cenyon that starts about 0.6 wiles east of the pond and goes alongside and betreen the tailings and evaporation ponds. The canyon busin is only 3.2 square wiles in area and naxim now is not expected to exceed 67 cubic feet a second over an nverage of $40 \mathrm{cfs}$. It is not expected thai this strean will do any dike damage, and no damage was evident.

Thereal ground water discharge occurs at funter Hot Springs about one-half ile north-northeast of the tailings pond and a near surface geotherwal anomaly is present over on eight square wile area north of Lakeview. Most wells in the area are shallow and Indicnte a static water level of about $20-40$ feet belou the surface. Logs of vells in Sections 4 and 9 reveal alternating clay and clay/gravel sediments in the upper 800 feet of ralley fill. The tailings are not believed to be saturated.

Analyses of ground water and surface water saples by the state of oregon frow around the tailings pile indicate no morement of radionuclides from the pile. Standing water nearby contuined 4 and less than 2 pCi per liter of alpha beta radioactivity, respectively. Ground water from nearby wells measured about the sane. Radium from one well north of the pile shrwed less than 0.1 pCi per liter.

It appears that adverse effects of the tailings on shallow ground water either have not occurred or have not yet been observed. It is unlikely that extensive migrations of westes away from the ponds has occurred. Migration of radioactivity downard to deeper aquifers is improbable because of extensive clay deposits and lack of a marked dowward flor gredient.

Site Visit

The site was visited on May 9, 1974, by the following personnel (team):

Robert $P$. Barney, Lucius PItixin, Inc., (Contractor to USABC), Grand Junction, Colorado,

WIIIiam L. Loppenbusch, Invironmental Protection Agency, Region $x$, Seattle, Washington,

George A. Boysen, Environmental Protection Agency, Office of

Radiation Programs, Las Vegas, Nevada,

George T. Toombs, State Health Division, Portlard, Oregon. 


\section{References}

1. Herritt, Robert c., The Etrective Metellurgy of Uraniun, Coloredo School of vines Research Inst., USABC Contract, 1971, p. 535 .

2. U. S. Environsental Protection ABency, Office of adiation Program, State and Comanity Sumary Reports for Radiation Surveys (unpublished reports) (Lakeview and Pine Creek. State of Oregon furniabed reports January 1973) Las Veges, lievads.

3. Enviranientel Raciation Survey, Lakeriew, Oregon, Preliminary Report. October 1973. BPA, Office of Rodiation Prograns, Las Vegas, Tevada. 


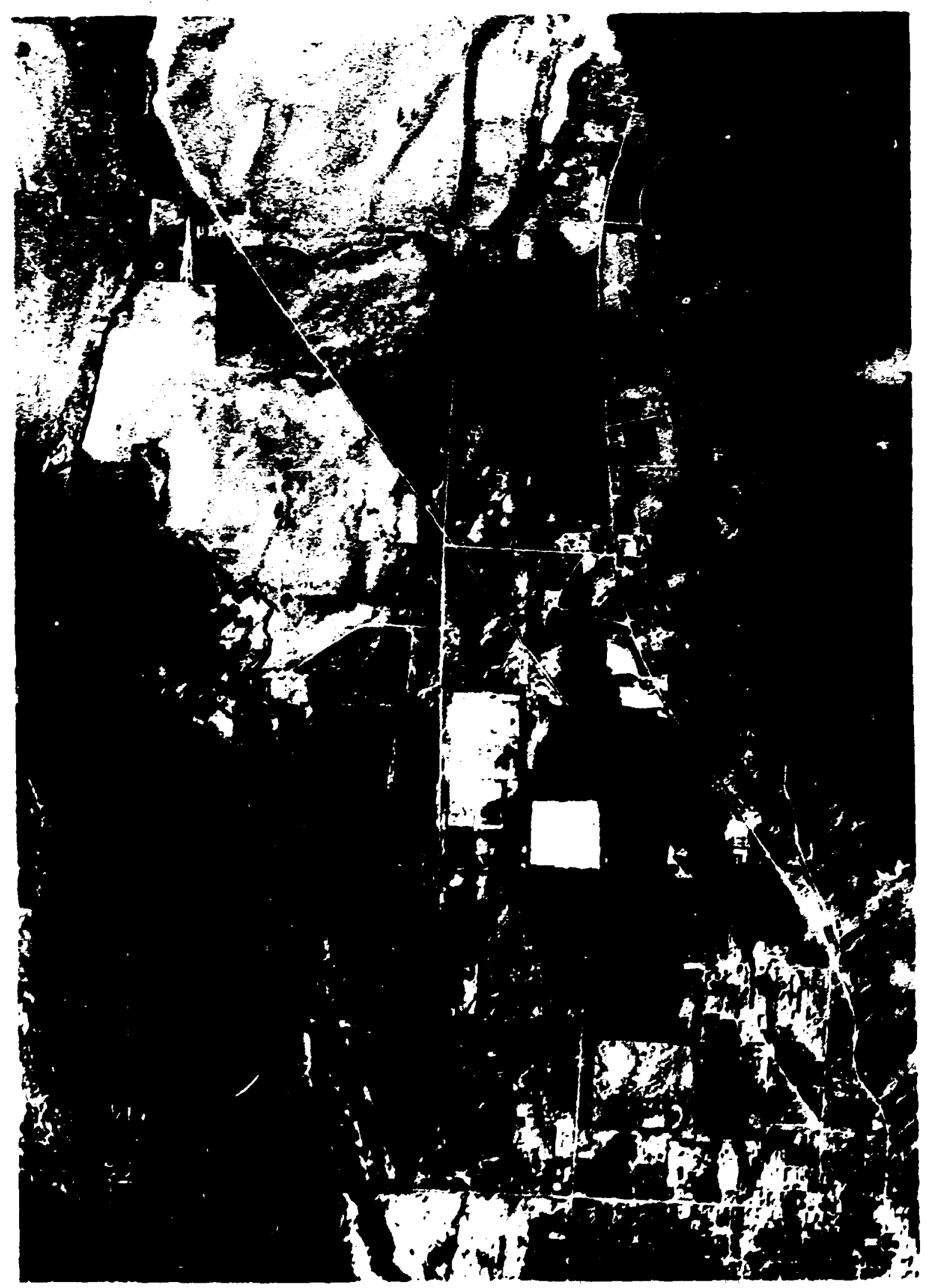

bakeview Sile - June 197 '

Aproximate Scale - Ine inch Equals 1, irso seat. 


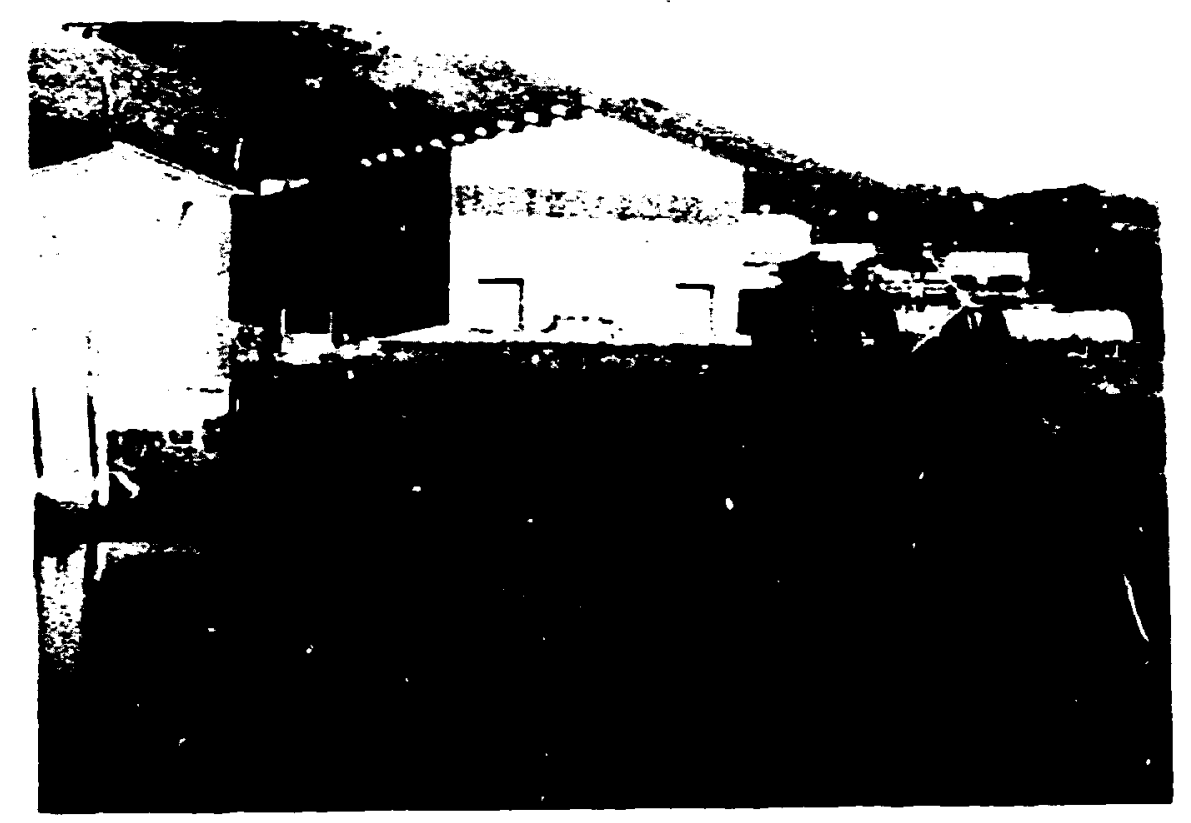

1. West side of mill building and CCD circuit. Smoll pond on tailings line.

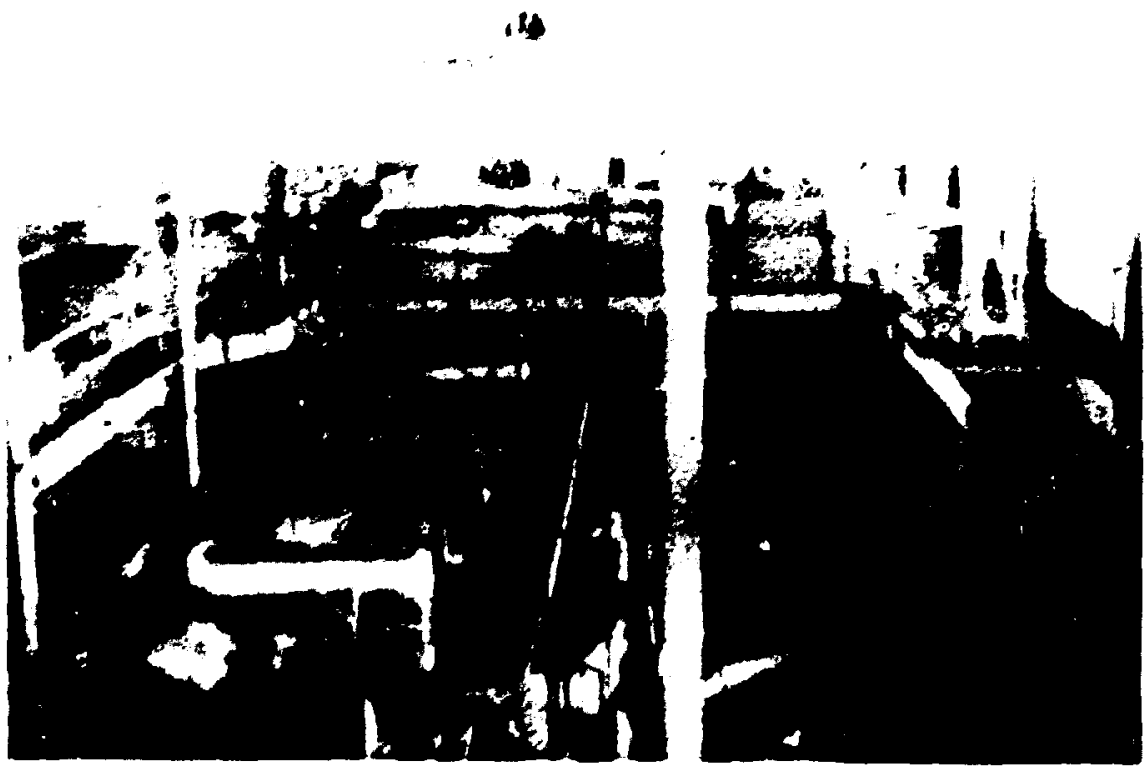

2. Interior of mill building looking toward weat wall. Note equipment still. in place. 


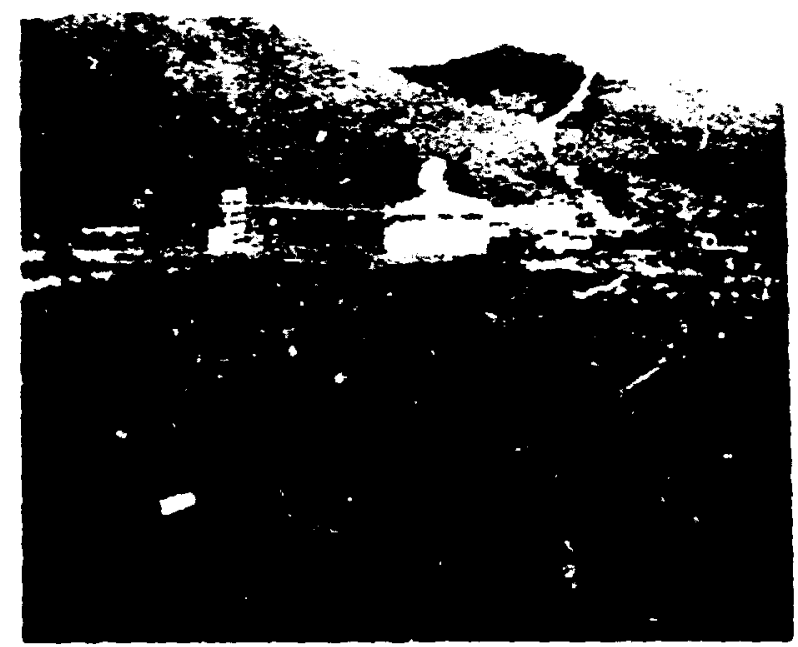

3. Mill building and sample plant. Note countryside and native vegetation.

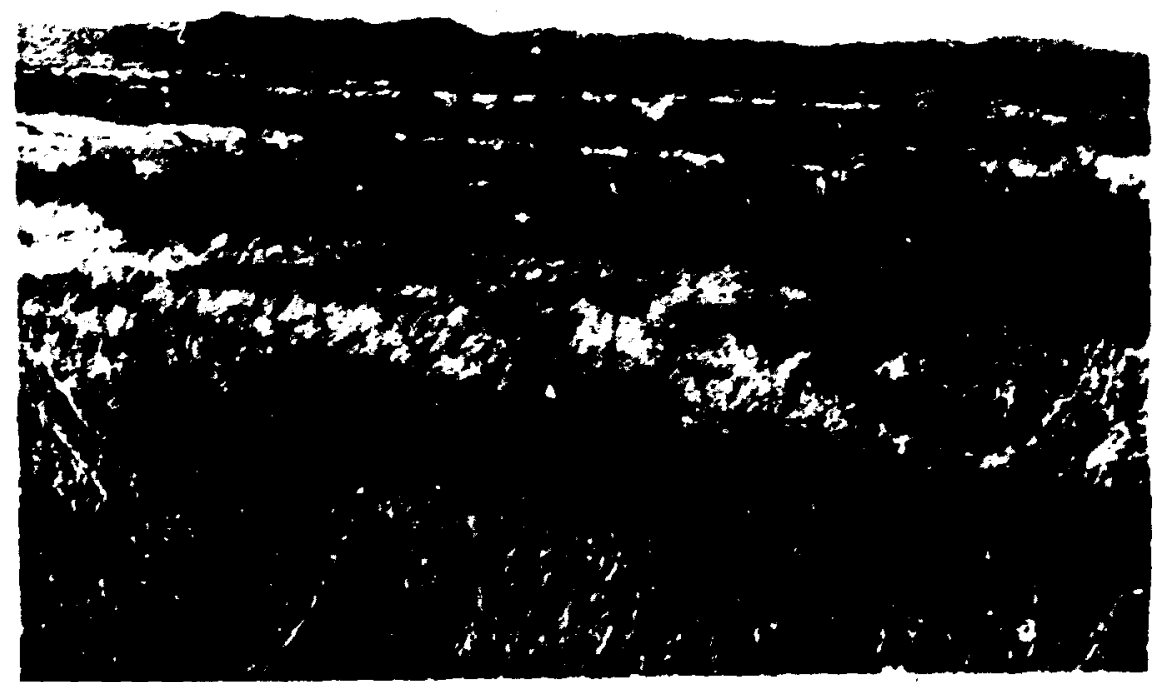

4. View of evnporation ponds from northwest corner of tailings pile. 


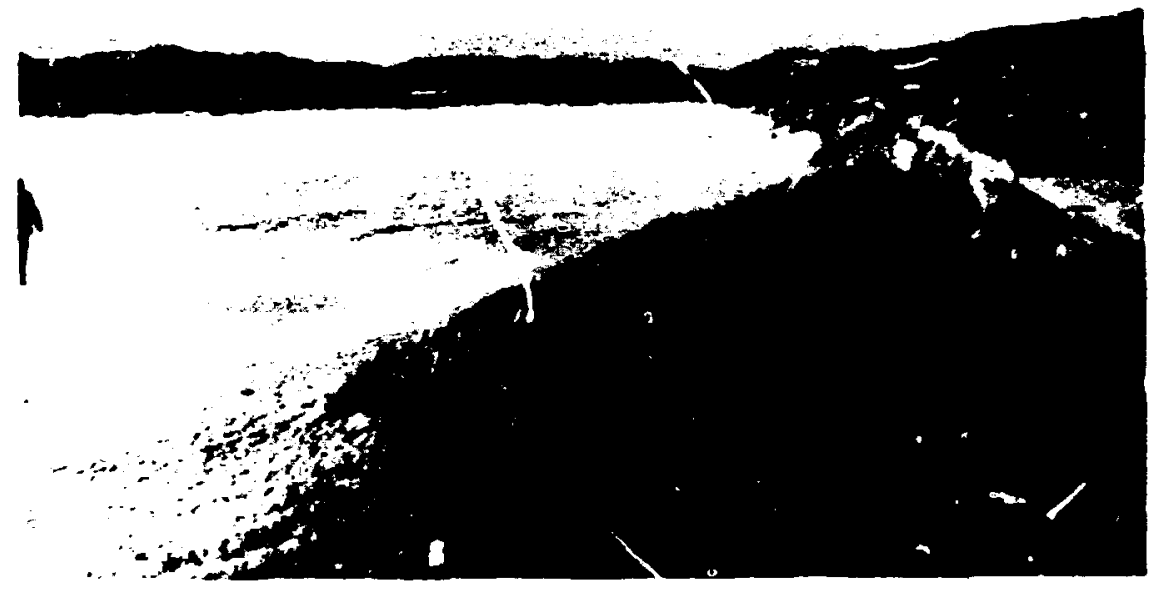

5. East dike of tailings pile showing vesetation and drainage ditch.

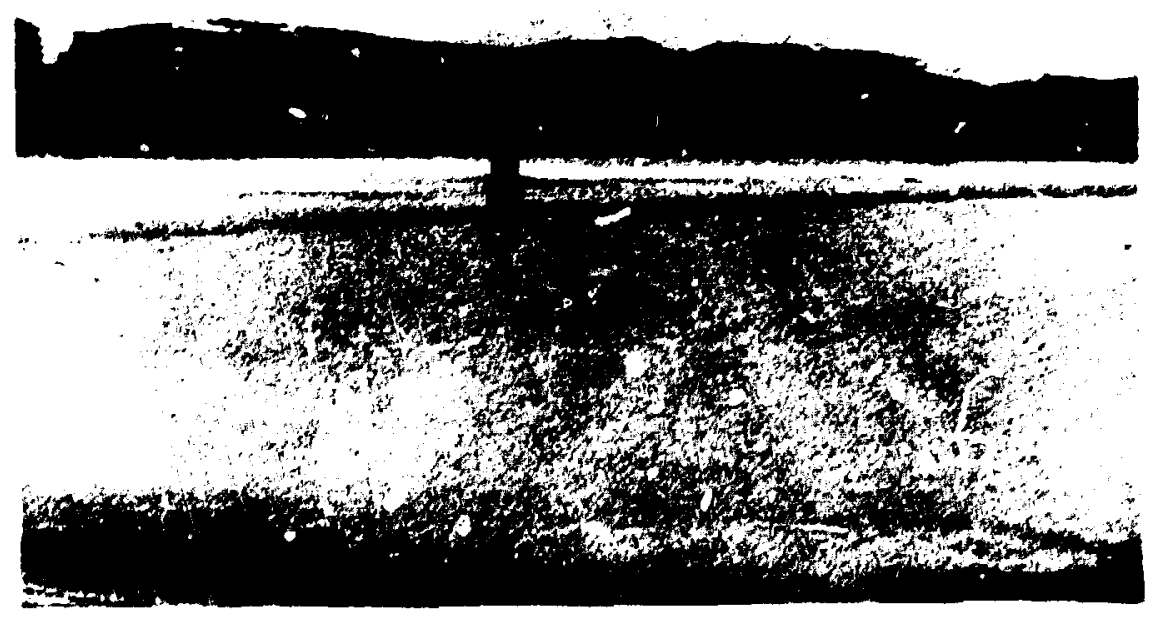

6. Drainage water in nortirwest corner of tallings pile and decent tower. 


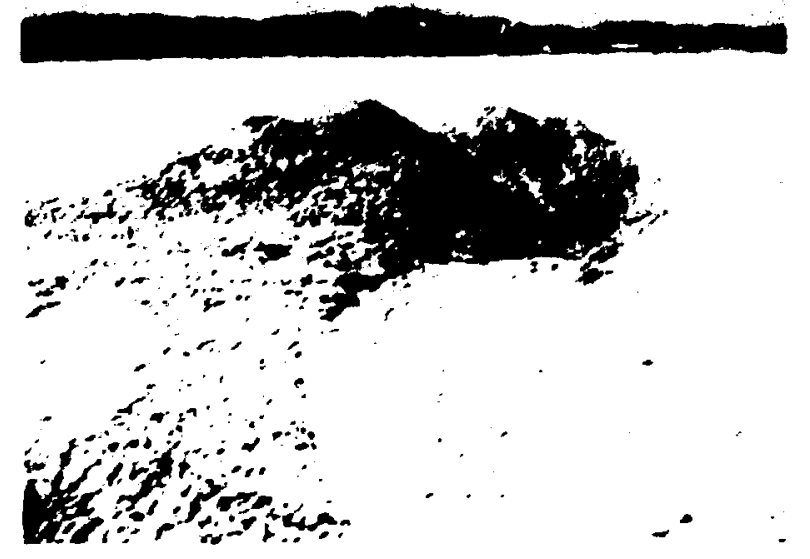

7. Apparent motorcycle jump in middle of tailings pond. 


\section{APPENDIX II}

Soil Sampling Techniques

and

Radiological Meacuremelits 
Soil Sampling and Measurement of Radionuclide Concentration as a Function of Depth in Soil

A monitoring and sampling procedure was established for this project in conjunction with FP\&OU to measure the radionuclide concentration in soil as a function of depth. At each site, a set of $15-\mathrm{cm}$ (6-in.) diameter holes was drilled through the tailings and into the subsoil. A polyvinyl chloride (PVC) pipe $(7.6 \mathrm{~cm} 0 . \mathrm{d})$, sealed on one end, was lowered into each hole, and measurements were made of gama-ray intensities as a function of depth. A $15-\mathrm{cm}-1$ long Geiger-Mueller tube shie!ded with a lead cover containing collimating slits was used for this purpose by lowering it inside the PVC pipe for measurements. Signals from this detector were counted using a portable scaler. ${ }^{1}$

After gamma-ray vs depth profiles were determined, the position of the interface between tailings and subsoil was estimated. Once completed, the drilling rig was moved approximately $1.2 \mathrm{~m}(4 \mathrm{ft})$, and another hole was drilled to the interface level. Samples of soil core were then collected as a function of depth using a split-spoon sampler (each core section was $0.6 \mathrm{~m}$ long).

Most of the penetrating gamna radiation monitored is attributable to ${ }^{226} \mathrm{Ra}$ and its daughters. Therefore, a calibration factor for ${ }^{226} \mathrm{Ra}$ concentration was determined for the collimated gamma-ray probe by comparing the response of this unit (counts per unit time) with a measured value for the radium concentration (picocuries per gram) in several soil samples determined by a gamma-ray spectrometry technique. A leastsquares $f i t$ of FB\&DU data (first probe) from this comparison yields the equation

$$
R=0.528(C-16)
$$

For this case, $R$ is the $226 \mathrm{na}$ activity in picocuries per gram and $C$ is the observed response 0 , the collimated gamma-ray detector in counts per minute; there were 16 background counts per minute for the gamma-ray detector. 
The above expression was useful in estimating the overall distribution of radioactivity in the tailings as well as the total quantity of radium in the tailings area. Surface soil samples were obtained normally by removal of an approximately $3-\mathrm{cm}$-deep layer of soil from an area of about $25 \times 25 \mathrm{~cm}$. The same procedure was used to obtain samples $15 \mathrm{~cm}$ ( 6 in.) below the surface except that the top $15-\mathrm{cm}$ layer of soil was discarded and the sample was removed from the next 3-cm layer.

Each sample was dried for $24 \mathrm{hr}$ at $110^{\circ} \mathrm{C}$ in order to remove moisture. The samples were then pulverized in a high speed rotary crusher having plates adjusted to provide particles no larger than $500 \mu \mathrm{m}$. The soil was dispensed into 25-ml polyethylene vials of the type used for liquid scintillation counting and sealed tightly. A soil sample normally consists of 12 of these vials. The net weight of the group of vials was measured to the nearest tenth of a gram.

The sealed sample vials were stored for a period sufficient to allow attainment of equilibrium between ${ }^{226}$ Ra and its short-lived daughters. Radon-222, which has a radioactive half-life of 3.8 days, will reach the same activity as its long-lived parent, ${ }^{226} \mathrm{Ra}$, in about 30 days. The short-lived progeny of ${ }^{222} R_{n}$ will have reached equilibrium within the same time. Determination of the activity of any of the daughters in the sample will reflect ${ }^{226}$ Ra activity. After equilibration of radon daughters, the 12 sample vials (or smaller number) were inserted into a sample carousel or holder ( $\mathrm{Fig}$. II-1) that was placed on a $\mathrm{Ge}(\mathrm{L} i)$ detector for counting as described in the section on gamma-ray spectrometry below.

\section{Field Laboratory Facilities and Equipment}

A 20-ft mobile laboratory van was used as a field office and for transporting instruments. This van contained an alpha spectrometry counting system for air samples along with air samplirig equipment; a Johnston Laboratory radon monitor complete with Lucas-type flasks and an evacuation manifold; gamma-ray detectors; miscellaneous electronic testing equipment; and standard calibration sources. A trailer-mounted, gasoline-powered $12 \mathrm{~kW}$ motor generator, pulled by the van, was used to 
ORNL-Photo $2171-75$

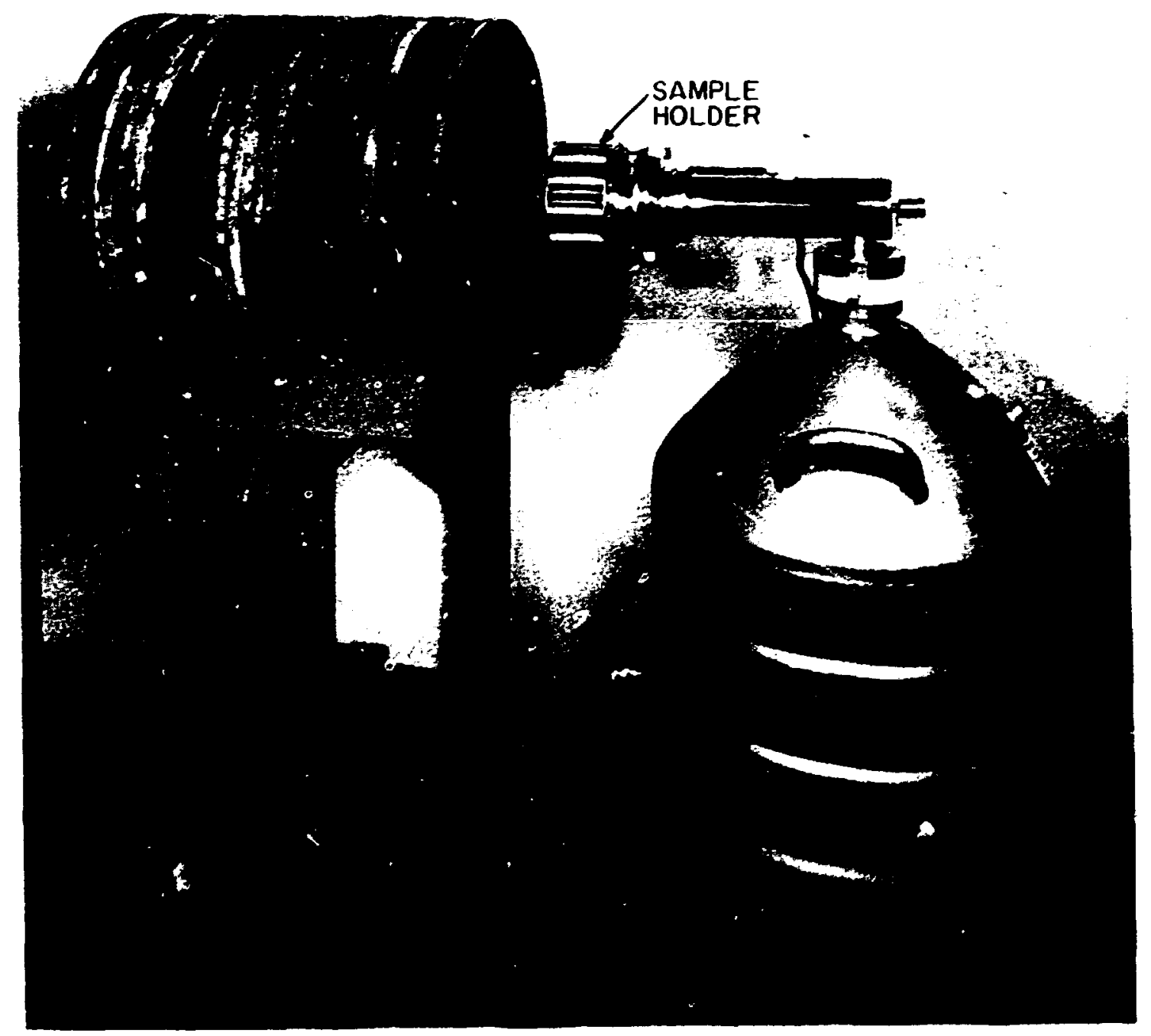

Fig. II-1. Horizontal mounted $\mathrm{Ge}(\mathrm{L} i)$ detector system used for counting soil samples (carousel-type sample holder is shown in its counting position). 
supply elecirical power in remote locations. A voltage stabilizer was used to provide regulated power for instruments.

A second field laboratory used in the project was an $8 \times 35 \mathrm{ft}$ airconditioned semitrailer with running water, tools, and miscellaneous supplies. It served as an instrument calibration facility, office, and workshop. This trailer required electrical power from an external source. During most of this project, the trailer was parked in Grand Junction and was used as a temporary field of ice.

\section{Gamma-Ray Spectrometry Systems}

A Harshaw integral $3 \times 3$ in. NaI (TI) c ystal, a high sensitivity detector, was used to scan all samples for a preliminary estimate of ${ }^{226} \mathrm{Ra}$ activity. This detector was used in a "pickie barrel" type shield, lined with copper and cadmium to shield $x$-rays. Signals from the crystal were sorted by a computer-based (PDP-11) pulse-height analyzer. The computer was programmed to control all functions of the analyzer and counter, to analyze the data, and to print out a statistically weighted average of the ${ }^{226}$ Ra activity per unit mass. One advantage of this counting arrangement is that it permits quick sorting; samples can be scanned at the rate of about six per hour (minimum counting pericd is $5 \mathrm{~min}) .^{*}$ An energy caliuration of the NaI crystal and analyzer was obtained by standardizing with ${ }^{57} \mathrm{Co},{ }^{137} \mathrm{Cs}$, and ${ }^{60} \mathrm{Co}$. An efficiency calibration was obtained through daily counting of a uranium standard $^{\dagger}(0.05 \%$ uranium mixed with dunite, particle size $=500 \mu \mathrm{m})$. Radium-226 is in equilibrium with the uranium, and this isotope and its daughters provide a source of gamma-ray lines for calibration.

\footnotetext{
*The principal reason for using this scanning system was to estimate how much time would be required to count the samples with one of thre? high resolutions $\mathrm{Ge}(\mathrm{Li})$ gamma-ray spectrometers.

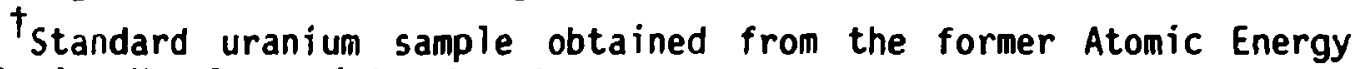
Commission New Brunswick Laboratory.
} 
Final data on the concentration of radionuclides in soil samples were deterwined by counting all samples with one of three high resolution $\mathrm{Ge}(L i)$ spectrometers. These high resolution counting systems consist of one horizontally wounted $50-\mathrm{cm}^{3} \mathrm{Ge}(L i)$ crystal positioned on a platform for movement into and out of a lead shield (Fig. II-1), and two vertically mounted detectors (Fig. II-2). The detector systems were used to obtain complete photon spectra of the soil samples. Signals from the horizontal $\mathrm{Ge}(\mathrm{Li})$ crystal were routed to a 4096-channel pulse height analyzer and signals from the other two Ge(Li) crystals were routed to two 2688 channel regions of a computer based pulse height analysis system. Sanples vere counted for periods long enough to evalwate the ${ }^{226}$ Ra concentration to a statistical accuracy of $\pm 5 \%$ or better. Spectra from the horizontally mounted $\mathrm{Ge}(\mathrm{Li})$ detector were recorded on magietic tape and stored for later analysis using the ORNL IBM computer system.*

The computers were programed to sort out peaks from ${ }^{232}$ Th daughters including the 909 and $967 \mathrm{keV}$ peaks from $228 \mathrm{AC}$, the $239 \mathrm{keV}$ from $212 \mathrm{~Pb}$, and the 2614 and $583 \mathrm{keV}$ peaks from ${ }^{208} \mathrm{Tl}$. These data permitted measurements of the ${ }^{232}$ Th concentration and data are reported for many of the samples.

Energy calibration of the $\mathrm{Ge}(\mathrm{Li})$ detectors was controlled through the use of isotopic sources of ${ }^{57} \mathrm{Co},{ }^{22} \mathrm{Na},{ }^{137} \mathrm{Cs},{ }^{60} \mathrm{Co},{ }^{88} \mathrm{Y}$, and ${ }^{40} \mathrm{~K}$. A calibration check was completed each day prior to beginning sample counting. In order to maintain linearity of the $A D C^{\prime} s$, a spectrum stabilizer was utilized. This instrument can be adjusted so that two individual photon energies are detected and maintained in two channels at separate ends of the scale. These two calibration points helped maintain an energy span of $1 \mathrm{keV}$ per channel. Efficiency calibration was obtained through the use of the same uranium ore standard samples as for the NaI crystal. An analysis of the counting data was accomplished

*Spectra from the two sertically mounted $\mathrm{Ge}(\mathrm{Li})$ detectors were stored on magnetic tape for record purposes, but were analyzed immediately using a Tennecomp Model TP-5/1I compuier-based analyzer. 
ORNL-Photo 6719-76

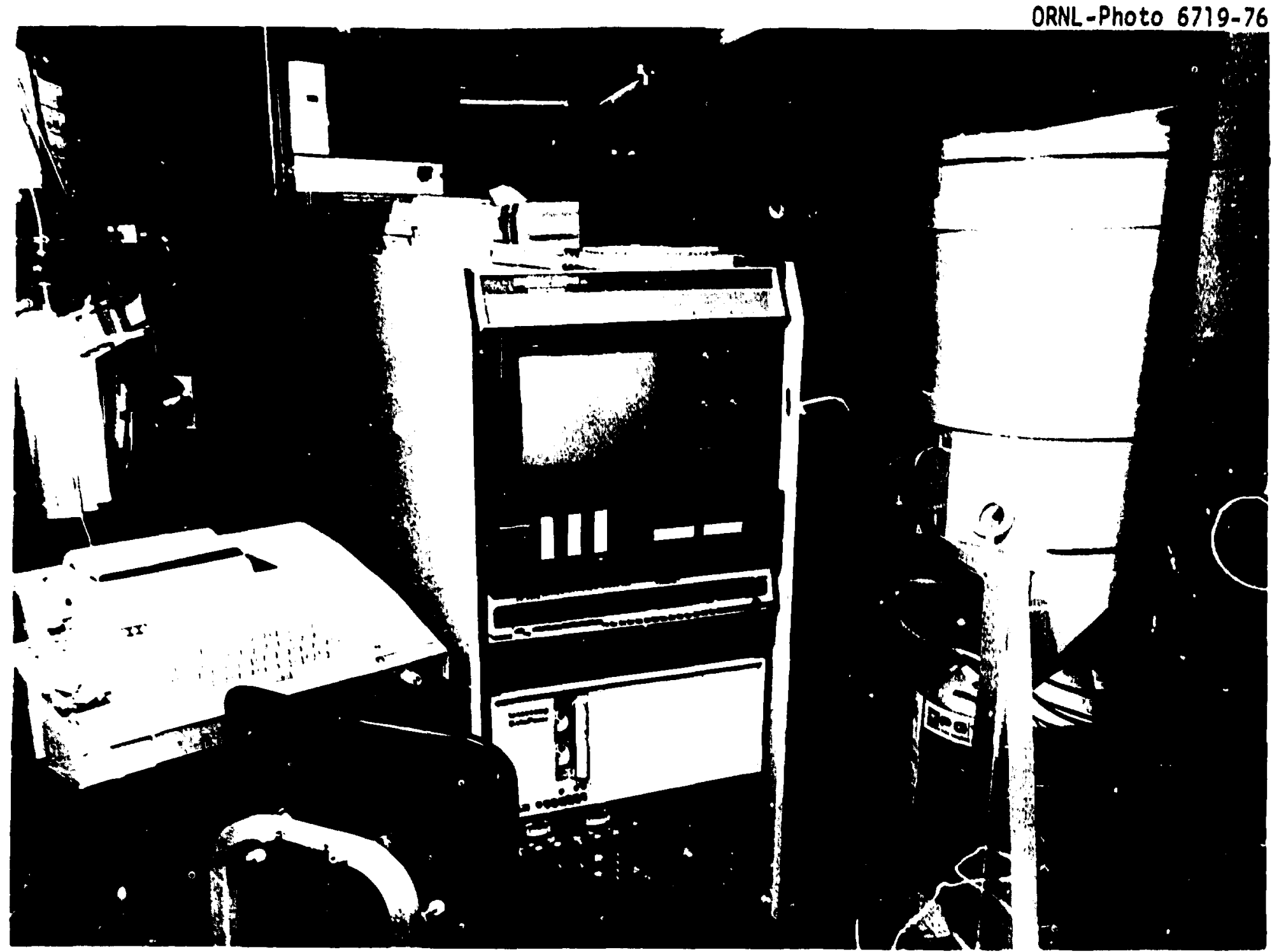

Fig. II-2. Computer based multichannel analyzer and one of three $\mathrm{Ge}(L 1)$ counting systems. 
through a linear least-squares fitting routine. Net adjusted areas under photo peaks of interest were compared with an extensive radionuclide library. ${ }^{2}$ Data from the computer were presented for each radionuclide as a weighted mean with standard deviation.

\section{External Gamma-Ray Detector}

A gamma radiation survey was made on and around the mill site and tailings pile. The instrument used for these measurements was a "Phil" gamma-ray dosimeter. 3 The basic unit was a $15-\mathrm{cm}$ - (6-in.) long $30-\mathrm{mg} /$ $\mathrm{cm}^{2}$ glass-walled organic-filled Geiger-Mueller (G-M) tube with an energy compensation shield made of tin and lead. Pulses from this unit were counted with a battery-powered portable scaler. Typically, G-M counters are not used for dosimeters because of a peaked response at low photon energies. However, perforated layers of tin $(1.0 \mathrm{~mm})$, and lead $(0.1 \mathrm{~mm})$, were used as an energy compensation filter to flatten this peaked response at photon energies below about $200 \mathrm{keV}$. Sealed sources of ${ }^{137} \mathrm{Cs}$ and ${ }^{226} \mathrm{Ra}$ were used for calibration. It was found that the response of this detector was: $1 \mathrm{mR} / \mathrm{hr}=3400$ counts $/ \mathrm{min}$.

For each gamma-ray-exposure rate measurement, at least three 1-min counts were recorded. The mean of these readings (less instrument background) was used to determine the exposure rate to external gamma rays.

\section{Radon Daughter Sampler*}

Radon daughter concentrations were measured with a sampling and counting instrument which has been in use at ORNL for several years, 4 and it was also used to make some comparative measurements in the remedial action program in Grand Junction. 5 The filter counter for this sampling cevice, shown in Fig. II-3, utilized a modified gas flow alpha

*This section and the following section contain descriptions of devices and methodologies typically used in the radiological surveys of milling facilities. They are included in each report in this series. However, in some instances, the measurements were not possible. 


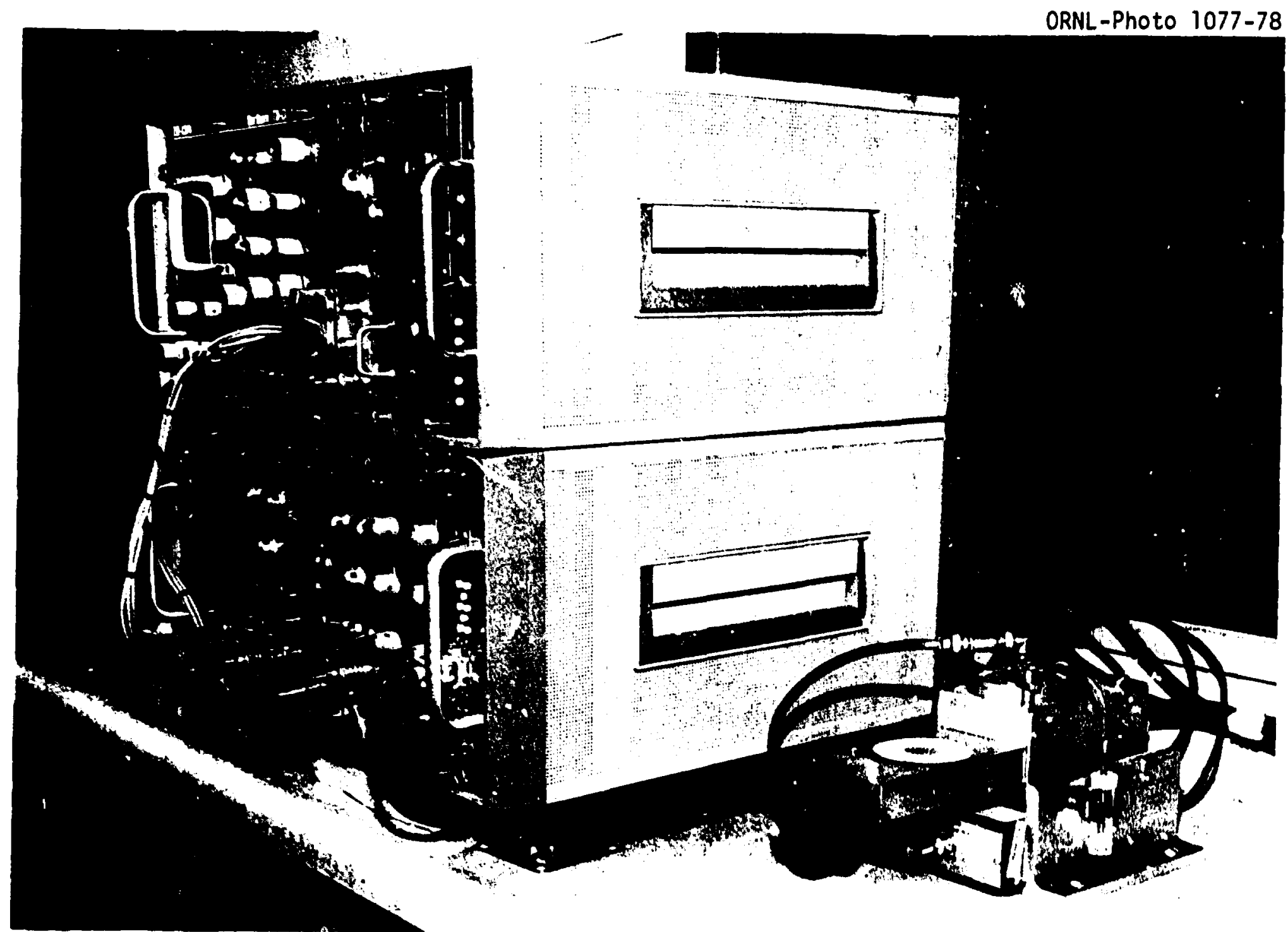

Fig. II-3. System used for measurement of radon daughter concentrations. 
counter for housing a 450- $\mathrm{mm}^{2}$ silicon diode. Normally, this type detector is operated in a vacuum chamber. However, in this case, it was found that by flowing helium at atmospheric pressure through the assembly, absorption of alpha particles is small relative to absorption in air. Alpha particle pulses were recorded with a 100-channel analyzer. A small 228Th alpha source standard was used for standardizing the energy scale. Air that was monitored for radon daughters was sampled at a rate of 12 to 14 liters/min. An absolute calibration of the airflow was provided through a comparison of the sampler's mass flow meter and a wet test meter. Samples were normally collected for $10 \mathrm{~min}$, and the first count of the filter was started at $2 \mathrm{~min}$ after removal of the sample and continued for $10 \mathrm{~min}$. For this case, a determination was made of the number of counts due to the decay of 218Po (RaA) and $214 \mathrm{Po}$ $\left(\mathrm{RaC}^{\prime}\right)$. A second count was started 15 min after removal of the sample and continued for $15 \mathrm{~min}$. In this case, counts were recorded from the decay of 214 Po. Data from the counter were stored in a pulse height analyzer and reduced by computer. The code for this analysis is explained in detail elsewhere. ${ }^{6}$ Results of the analysis of data using this code were presented as concentrations of RaA, RaB, and RaC'. In addition, a value for the working level concentration was also provided along with an estimate of the error associated with each reported value.

\section{Radon Monitor}

The instrument used by ORNL to measure radon concentrations in air consisted of 95-ml Lucas chambers and a readout unit. * Each chamber was evacuated to approximately $1 \mathrm{~mm} \mathrm{Hg}$ and then opened to atmospheric pressure in the area where a radon measurement was required. No filtration was used for sampled air. The short-lived daughters of radon drawn into the chamber were allowed to decay for 3 to $4 \mathrm{hr}$ prior to counting the flask. Comparison of the results from this instrument and the radon

*LLRC-2 Low Level Radon Counting System manufactured by Johnston Laboratories, Inc. , Baltimore, Md. 
progeny monitor provided an estimate of the degree of equilibrium between radon and its daughters in the selected locations where air samples were taken. 


\section{APPENDIX II REFERENCES}

1. J. H. Thorngate and J. E. Parks, "A Portable Scaler," Health Phys. 12 , 385-393 (1965).

2. J. F. Finery and F. F. Dyer, "Multi-Element Determination in Environmental Neutron Activation Analysis Using MONSTR," Proceedings of the Second Intermatiunal Conference on nuclear Methods and Envircnmental Research, CONF-740701, held at the University of Missouri, Columbia, Mo., July 29-31, 1974.

3. E. B. Wagner and G. 5. Hurst, "A Geiger-Mueller y-Ray Dosimeter with Low Neutron Sensitivity," Health Phys. 5, 20-26 (1961).

4. P. T. Perdue, W. H. Shinpaugh, J. H. Thorngate and J. A. Auxier, "A Convenient Counter $f($ - Measuring Alpha Activity of Smea.- and Air Samples," Health Phys. 26, 114-116 (1974).

5. G. D. Kerr, "Measurenents of Radon Daughter Concentrations in Air," pp. 202-207 in Dosimetry for Homom Exposures and Radiological Impaet, ORNL-4979 (JuTy 1974).

6. G. D. Kerr, Heasurement of Radon Progeny Concentrations in Air by Alpha-Particle Spectrometry, ORNL-TM-4924 (Ju1y 1975). 


\section{APPENDIX III}

Water Sampling and Analysis

Water samples are obtained at appropriate points on and around the mill site, labeled and stored for later allalys is. Each sample is centrifuged and filtered through a $0.45-\mu \mathrm{m}$ filter to remove suspended solids. The samples are then analyzed by radiochemical techniques as described in this appendix. 
Procedure for the Eequential Determination of ${ }^{226} \mathrm{Ra},{ }^{230} \mathrm{Th}$, and $210 \mathrm{~Pb}$ in Wate, from Uranium Mill Tailings Sitas

P. M. Lantz

Health and Safety Research Division

Oak Ridge National Laboratory

Oak Ridge, Tennessee

\subsection{Radium-226}

1.1 Filter the 21.0 liter water sample using a vacuum flask and \#42 Whatman filter paper to remove suspended particles.

1.2 Reduce the volume of the water sample, to which $10 \mathrm{ml}$ of concentrated $\mathrm{HNO}_{3}$ has been added, to less than $250 \mathrm{ml}$ by evaporation.

1.3 Transfer the solution to a 250-ml, long-neck, tapered-joint, flat-bottom Pyrex boiling flask. Insert a Teflon-coated magnetic stirring bar. Add $37 \mathrm{ml}$ of concentrated $\mathrm{HNO}_{3}$ to make the final concentration $3 \%$. Insert the moditied, female, tapered joint with gas diffuser and side arm with stopcock. Seal off the gas inlet and close the stopcock to assure containment of ${ }^{222} \mathrm{Rn}$ in the flask. Store for at least 30 days to await attainment, of ${ }^{226} \mathrm{Ra}-222 \mathrm{Rn}$ equilibrium.

1.4 Next, connert the 250-ml de-emanation flask to a helium source and thie radon trapping system. Attach an evacuated Lucas chamber. Flush the system with helium gas while bypassing the flask. Stop the gas flow. Immerse the unfired Vycor radon concentrator in a liquid nitrogen bath. Be sure the upstream exit for belium gas is open. Start the magnetic stirrer. Open the flask side arm stopcock to the system and start helium gas flowing through the liquid at a rate not to exceed 2.8 liters $/ \mathrm{hr}$. The radon-helium stream is dried and stripped of organic condensable components by $\mathrm{KOH}$ and ascarite traps. Radon is condensed on the Vycor at liquid nitrogen temperature and thus separated from the helium gas carrier. 
1.5 Stop the de-emanation process after $30 \mathrm{~min}$. Having shut off the gas flow, close the helium exit. Isolate the radon trap and the evacuated Lucas chamber from the remainder of the system via stopcocks.

1.6 Open the Lucas chamber stopcock and remove the liquid nitrogen from the radon trap to allow the gaseous radon to diffuse into the chamber. To hasten the diffusion, the trap may be gently flamed.

1.7 Bypassing the flask, use a controlled stream of helium to flush residual radon into the Lucas chamber until near atmospheric pressure has been reached. Stop the gas flow and close the stopcock on the Lucas chamber.

1.8 After a delay of 3.0 to $3.5 \mathrm{hr}$ to permit the ${ }^{222} \mathrm{Rn}$ to reach equilibrium with its daughters, place the Lucas chamber over a photomultiplier tube and count the gross alpha for $30 \mathrm{~min}$.

1.9 Subtract the Lucas chamber background, counted under the same conditions, from the gross count. Divide the net count by three to obtain the ${ }^{222} \mathrm{Rn}$ count at that time. Correct the count for time elapsed since de-emanation was terminated and the efficiency of the Lucas chamber for converting alpha discharges to scintillations ( $285 \%)$. Report the ${ }^{226} \mathrm{Ra}$ in equilibrium with ${ }^{222}$ Rn as picocuries per liter.

2.0 Thorium-230

2.1 Transfer one-half of the water sample remaining from the radon de-emanation process $\left(3: \mathrm{HNO}_{3}\right.$ ) to a Pyrex beaker for volume reduction on a magnetic stirrer hot plate.

2.2 Add $0.7 \mathrm{~g} \mathrm{Al}\left(\mathrm{NO}_{3}\right)_{3} \cdot 9 \mathrm{H}_{2} 0,2.0 \mathrm{ml}$ (20 mg) $\mathrm{Pb}$ carrier, $1.0 \mathrm{ml}$ (20.9 mg) Bi carrier and 5,000 to $10,000 \mathrm{cpm}$ of $234 \mathrm{Th}$ tracer to the water sample before reducing the volume to approximately $20 \mathrm{ml}$.

2.3 Should the sample solution contain undissolved salts, separate liquid and solids by use of centrifuge. Dissolve the 
solids by heating with a minimum volume of distilled water or dilute $\mathrm{HNO}_{3}$. Combine the dissolved solid with the original supernate. Should silicic acid form in the solution during volume reduction, as evidenced by its deposition on the beaker walls, cool the solution to room temperature and centrifuge. Add an equal volume of concentratud $\mathrm{HNO}_{3}$ to the supernate. Wash the solids with a small volume $(5.0 \mathrm{ml})$ of $8: \because \mathrm{HNO}_{3}$ and centrifuge. Combine the wash with the adjusted supernate. Discard the solids. Keep the solution cool in an ice bath during precipitation of hydroxides with an excess of ammonium hydroxide to minimize the formation of silicic acid from dissolved silicates. Let stand 5 to 10 min. Centrifuge, pour of $f$ the supernatant liquid, and wash the precipitate with dilute ammonium hydroxide. Discard the supernatant and wash liquids. Dissolve the solids in 10-20 $m l$ of $8 \because \mathrm{HNO}_{3}$. Should the solution contain suspended silicic acid, centrifuge, wash the jolids with $5 \mathrm{ml}$ of $8 \because \because \mathrm{HNO}_{3}$ and combine the supernatant liquias. Discard the solids.

2.4 Transfer the $8: \because \mathrm{HNO}_{3}$ solution to a conditioned Dowex $4 \times 1$ anion exchange column $5 \mathrm{~mm}$ i.d. $x 10 \mathrm{~cm}$ long ( $2.0 \mathrm{ml}$ vol.). The column is conditioned by passing through it at least 5 column volumes $(10 \mathrm{ml})$ of $8 \because \mathrm{HNO}_{3}$. The anion-complexed thorium adsorbs on the resin column to the exclusion of the cations. Wash the column with $10 \mathrm{ml}$ of $8 \% \mathrm{HNO}_{3}$ to remove residual bismuth. Combine the effluent and wash solutions, and save them for lead and bismuth recovery.

2.5 Strip the thorium from the column with $5.0 \mathrm{ml}$ of distilled water followed by $10 \mathrm{ml}$ of $6 \because: \mathrm{HCl}$.

2.6 Convert the chloride to the nitrate by adding an excess of $\mathrm{HNO}_{3}$ and reducing the solution to near dryness on a hot plate. Dissolve the solids in $5.0 \mathrm{ml}$ of $0.1 \mathrm{HNO}$.

2.7 Transfer the $0.1 \because \mathrm{HNO}_{3}$ solution to a conditioned Dowex $50 \times$ $1 \mathrm{~mm}$ cation exchange $2.5 \mathrm{~mm}$ i.d. $\times 7 \mathrm{~cm}$ long ( $0.4 \mathrm{ml}$ vol.). The column is conditioned by passing $5.0 \mathrm{ml} 8 \mathrm{MHNO}_{3}$ through 
it and then washing it free of excess acid with distilled water as indicated by litmus paper.

2.8 Wash the column with $5.0 \mathrm{ml}$ of $2 \mathrm{M} \mathrm{HCl}$ to remove traces of bismuth and other weakly bound cations.

2.9 Strip the thorium with $5.0 \mathrm{ml}$ of $8 \mathrm{M} \mathrm{H} \mathrm{HO}_{3}$ and reduce the volume of the solution to a few drops by evaporation.

2.10 Transfer the solution with a suitable pipette onto a 2-in. stainless-steel disc supported on a hot plate by a steel washer 0.75 in. i.d. $\times 1.5$ in. $0 . d$. Dry slowly to minimize the deposit area at the center of the disc. Fire the disc to red heat with a gas torch to remove carbonaceous materials.

2.11 Determine the thorium yield by counting the ${ }^{234}$ Th beta with an end window counter and compare it with a mounting of like count of the ${ }^{234}$ Th tracer used in the analysis.

2.12 Determine the ${ }^{230} \mathrm{Th}$ alpha disintegrations per minute (dpm) by pulse-height analysis using a diode pickup in a helium atmosphere. Compare the counts of ${ }^{230} \mathrm{Th}$ alpha in the sample with those in a ${ }^{230} \mathrm{Th}$ standard mounting whose dpm is known.

2.13 To correct for the contribution of ${ }^{230} \mathrm{Th}$ which may be in the ${ }^{234}$ Th tracer, pulse analyze the 234Th mounting. Subtract the contribution from the tracer after correcting for yield to obtain the net ${ }^{230}$ Th content of the water sample.

2.15 Calculations

$$
{ }^{230} \operatorname{Th}(\mathrm{pC} \mathrm{i} / \mathrm{liter})=\frac{\mathrm{AB}}{\mathrm{CDEF}},
$$

where

$$
\begin{aligned}
& A=\text { Water sample net alpha }(\mathrm{cpm}) \\
& B={ }^{230} \mathrm{Th} \text { standard }(\mathrm{dpm}) \\
& C={ }^{230} \mathrm{Th} \text { standard }(\mathrm{cp}: \mathrm{m}) \\
& D=\text { Fraction of }{ }^{234} \mathrm{Th} \text { tracer recovered } \\
& E=\text { Volume of sample (liter) } \\
& F=2.22 \mathrm{~d} /(\mathrm{m} \cdot \mathrm{pCi})
\end{aligned}
$$


3. 0 Lead-210

3.1 Evaporate the Dowex $4 \times 1$ effluent and wash from Step 2.4 to $\sim 20 \mathrm{ml}$. Cool and slowly add ammonium hydroxide, while stirring in an ice bath, until hydroxide precipitation barely starts. Add 1 to 2 drops of concentrated $\mathrm{HNO}_{3}$ to each $10 \mathrm{ml}$ of solution to give an acidity of 0.2 to $0.4 \%$.

3.2 Slowly bubble $\mathrm{H}_{2} \mathrm{~S}$ through the chilled solution to precipitate metal sulfides. Let the mixture stand 10 to $15 \mathrm{~min}$ and centrifuge. Discard the supernate. Wash the sulfides with 5 to $10 \mathrm{ml}$ of $\mathrm{H}_{2} \mathrm{~S}$-saturated $0.2 \mathrm{M} \mathrm{HNO} \mathrm{H}_{3}$ solution. Centrifuge and discard the wash.

3.3 Dissolve the sulfide precipitate in a minimum of concentrated $\mathrm{HNO}_{3}$ by heating in a. hot water bath. Dilute with 5 to $10 \mathrm{ml}$ of distilled water and filter out the suspended sulfur on \#42 Whatman filter paper. Hash out the centrifuge tube and filter with 5 to $10 \mathrm{ml}$ of distilled water.

3.4 Transfer the solution to a centrifuge tube and precipitate the hydroxides with an excess of ammonium hydroxide. Digest 10 min in a hot water bath. Cool, centrifuge, and wash the precipitate with 5 to $10 \mathrm{ml}$ of dijute $\mathrm{NH}_{4} \mathrm{OH}$. Discard the supernatant and wash liquids.

3.5 Dissolve the hydroxides in a minimum of concentrated $\mathrm{HNO}_{3}$ and dilute to $10 \mathrm{ml}$. Add $0.5 \mathrm{ml}$ of concentrated $\mathrm{H}_{2} \mathrm{SO}_{4}$ to precipitate $\mathrm{PbSO}_{4}$. Digest $15 \mathrm{~min}$ in a hot water bath, cool, centrifuge, and wash the $\mathrm{PbSO}_{4}$ with distilled water. Save the supernatant and wash liquids for bismuth recovery.

3.6 Transfer the $\mathrm{PbSO}_{4}$ slurry onto a tared 42 Whatman filter paper disc which is supported by the perforated fixed plate of a Hirsch funnel. Dry the $\mathrm{PbSO}_{4}$ and paper with ethyl alcohol followed by ethyl ether.

3.7 Weigh the filter paper and $\mathrm{PbSO}_{4}$ to determine the yield of $210 \mathrm{~Pb}$. Store the $210 \mathrm{PbSO}_{4}$ sample iu. 30 days to allow the $210 \mathrm{~Pb}$ to reach equilibrium with its $210 \mathrm{Bi}$ daughter. The $210 \mathrm{Bi}$ beta is counted in a low-level gas-proportional counter with a 
1-mil-thick polystyrene cover to shield out any stray alpha emissions.

3.8 Add pellets of $\mathrm{NaOH}$ to the bismuth solution from Step 3.5 to precipitate bismuth hydroxide. Digest for 10 min in a hot water bath, cool, and centrifuge. Wash the precipitate with $10 \mathrm{ml}$ of distilled water. Discard supernatant and wash liquids.

3.9 Dissolve the solids in a minimum of $\mathrm{HNO}_{3}$. Add 3-4 drops of concentrated $\mathrm{HCl}$ and dilute to $240 \mathrm{ml}$ with hot distilled water to precipitate BiOCl. Digest for $245 \mathrm{~min}$ in a hot water bath or until the precipitate has settled.

3.10 Pour the hot supernatant liquid through a tared \#42 Whatman filter paper supported by a perforated, fixed-plate, Hirsch funnel. Slurry the BiOCl onto che filter paper disc with small portions of hot distilled water. By means of a stirring rod, guide the deposit to the center of the disc. Ory with ethyl alcohol and ethyl ether.

3.11 Weigh the $\mathrm{BiOCl}$ and filter paper in order to determine yield.

3.12 Count the 5.01 day ${ }^{210} \mathrm{Bi}$ beta, which is in equilibrium with $210 \mathrm{~Pb}$, in a low-level, gas-proportional counter. The counting efficiency of the counter is determined by counting several similar mountings having known $210 \mathrm{Bi}$ disintegration rates, with varying weights of $\mathrm{BiOCl}$ from which a calibration curva is constructed.

3.13 Refer to the calibration curve and convert cpm to dpm by means of an efficiency factor for the weight of sample in question.

3.14 Calcuiation

$$
210 \mathrm{~Pb} \rightarrow 210 \mathrm{Bi}(\mathrm{pCi} / 1 \text { iter })=\frac{A B}{\mathrm{CDEF}},
$$

where

$$
\begin{aligned}
A= & \text { Beta count minus background }(\mathrm{cpm}) \\
B= & \text { Correction for decay from } \mathrm{Pb} \text { separation time } \\
& \text { to counting time }
\end{aligned}
$$


$C=$ Counter efficiency

$D=$ Fraction of $B i$ recovered

$E=$ Volume of sample (liter)

$F=2.22 d /(m \cdot p C i)$

\subsection{Reagents}

4.1 Aluminum nitrate.

4.2 Lead carrier, $10 \mathrm{mg} / \mathrm{ml}$. Oissolved $8.0 \mathrm{~g} \mathrm{~Pb}\left(\mathrm{NO}_{3}\right)_{2}$ in dilute $\mathrm{HNO}_{3}$ and dilute to 500 with water.

4.3 Bismuth carrier, $20.9 \mathrm{mg} / \mathrm{ml}$. Dissolve $5.225 \mathrm{~g}$ bismuth metal in concentrated $\mathrm{HMO}_{3}$ and dilute to $250 \mathrm{mith}$ water.

4.4 Thorium tracer, ${ }^{234} \mathrm{Th}$. Piatreat a $30 \%$ Adogen 364-xylene solution by extracting it with an equal volume portion of $2: \mathrm{HNO}_{3}$ for $2 \mathrm{~min}$. Dissolve $5.0 \mathrm{~g}$ of recently depleted ${ }^{238} \mathrm{U}$ (as $\mathrm{U}_{3} \mathrm{O}_{8}$ ) in $2 \because \mathrm{HNO}_{3}$. Extract the thorium and uranium with an equal volume of pretreated $30 \%$ Adogen 364-xylene in a separator flask by hand shaking at least $2 \mathrm{~min}$. Separate phases and strip thorium from the solvent with $10 \mathrm{ml}$ of $10 \% \mathrm{HCl}$. Convert the chloride solution to $2 \because \mathrm{HNO}_{3}$ solution for a repeat extraction with solvent to remove traces of uranium. The second $10 \mathrm{M} \mathrm{HCl}$ strip is again converted to the nitrate for counting the ${ }^{234}$ Th beta on a stainless steel disc. The mounting should be examined in a pulse-height aipha anaiyzer for the pres ...ce of ${ }^{230} \mathrm{Th}$. Should the ${ }^{230} \mathrm{Th}$ level be significant, then another source of depleted ${ }^{238} \mathrm{U}$ should be sought, or alternatively extract the ${ }^{234} \mathrm{Th}$ from a batch of ${ }^{238} \mathrm{U}$ from which the thorium had been extracto 1 to 2 months previously.

4.5 Ammonium hydroxide, concentrated.

4.6 Nitric acid, concentrated.

4.7 Hydrochloric acid, concentrated.

4.8 Sodium hydroxide pellets.

4.9 Sulfuric acid, concentrated. 
4.10 Hydrogen sulfide gas.

4. 11 Dowex $4 \times 1$ and Dowex $50 \times 1$ exchange resins.

\subsection{Apparatus}

5.1 Radon de-emanation train with radon concentrator* and Lucas chamber.

5.2 Radon photomultiplier counter.

5.3 Modified ${ }^{\dagger}$ 250-ml, flat-bottom, boiling flasks.

5.4 0ther counting equipment--G-M beta counter; low-level, gasproportional beta counter; pulse-height spectral alpha analyzer.

5.5 Stainless-steel alpha counting discs.

5. 6 Laboratory centrifuge.

5.7 Pyrex centrifuge tubes, $50 \mathrm{ml}$.

5.8 Beakers, assorted.

5.9 Ion exchange columns.

5. 10 Dowex $4 \times 1$ and Dowex $50 \times 1$ exchange resins.

5.11 Hirsch fixed plate funnel.

*The radon concentrator consists of a $20-\mathrm{cm}$ - long $\mathrm{U}$-tube constructed from $6 \mathrm{~mm}$ o.d. Pyrex glass tubing. Ten centimeters of the U-section is filled with 20 to 40 in. unfired Vycor which has a large surface to volume ratio. When the tube is immersed in liquid nitrogen and radonladen helium gas passes through the tube, the condensable radon adheres to the Vycor surface. The stripped helium gas exits the system. Upon removal of the coolant the radon yaper diffuses through 10 to $15 \mathrm{~cm}$ of capillary tubing to the evacuated Lucas chamber. Flushing the U-tube and attached capillary tubing with 20 to $30 \mathrm{ml}$ of helium transfers essentially $100 \%$ of the radon to the Lucas chamber. Since the efficiency of Lucas chambers for counting alphas may vary from 75 to $85 \%$, it is necessary to calibrate each chamber with an equilibrated ${ }^{226} \mathrm{Ra}$ standard solution.

The radium-radon equilibrating flask consists of a flat-bottom 250-ml boiling flask with a female 24/40 tapered joint. A saber-type sintered glass gas diffuser is sealed into a male 24/40 taper joint section so that when it is inserted in the flask it will extend well into the equilibrating solution. A suitable inlet gas connection is provided on the opposite end of the diffuser tube. Onto the shoulder of the male $24 / 40$ joint is sealed a short length of small bore ( $5 \mathrm{~mm}$ i.d.) glass tubing with a glass stopcock terminating with a connector suitable for hooking up with the rädon trapping system. 